\title{
Türkiye'de KOVİD-19 ile Mücadele: Politikalar ve Aktörler
}

\author{
Fight Against COVID-19 in Turkey: Policies and Actors
}

\author{
Abdulmenaf TURAN \\ Prof. Dr., Van Yüzüncü Yll Üniversitesi, \\ İ̈F, Кати Yönetimi Bölümü, \\ mturan@yyu.edu.tr \\ https://orcid.org/0000-0001-7536-7630
}

Makale Başvuru Tarihi: 07.05.2020

Makale Kabul Tarihi: 15.05.2020

Makale Türü: Araştırma Makalesi

\author{
Hicran HAMZA ÇELIKKYAY \\ Dr. Ögrr. Üyesi, Düzce Üniversitesi, Akçakoca Bey SBF \\ Siyaset Bilimi ve Kamu Yönetimi Bölümü, \\ hicrancelikyay@duzce.edu.tr \\ https://orcid.org/0000-0002-4256-1397
}

\section{Anahtar \\ Kelimeler:}

Türkiye,

Kamu Politikası,

Risk Yönetimi,

Kriz Yönetimi,

KOVID-19,

\section{Keywords:}

Turkey,

Public Policy,

Risk Management,

Crisis Management,

COVID-19,

\section{ÖZET}

Bu yazının konusu, 2019 yılının Aralık ayında Çin'de ortaya çıkan ve kısa süre içerisinde küresel düzeye yayılan, ölümcül KOVID-19 salgını ile Türkiye'nin mücadelesini, izlediği politikaların ve aktörlerin üzerinden analizidir. Günümüz toplumlarını belirsizlikler içeren risk toplumu olarak niteleyen yaklaşımlardan esinlenilerek biyolojik bir afet türü olan salgınla mücadele, önce afet yönetimi sürecinin iki önemli unsuru olan risk yönetimi ve kriz yönetimi kavramlarlyla ilişkilendirilmekte ardindan Türkiye'nin her iki aşamaya denk gelen politikaları kamu politikası yaklaşımlarından süreç yaklaşımı yardımıyla aşamalar halinde değerlendirilmektedir. Yazının amacı, Türkiye'nin risk yönetimi süreci kapsamında değerlendirilen hazırlık planı ve sağllk altyapısı ile kriz yönetimi aşamasında benimsemiş olduğu tedbir stratejisi kapsamında salgına müdahalesi, toplumsal bilinçlendirme çalışmaları, sosyal hareketliliğinin azaltılması, ulaşım ve dolaşımın sınırlandırılması, ekonomik düzenlemeler, toplumsal yardımlaşma ve dayanışma ile aşamalı normalleşme süreçlerini ele almaktır. Özellikle toplumun açılklk ve şeffaflı ilkeleri doğrultusunda bilgilendirilmesi, uygulanan politikaların kanıta dayalı olarak belirlenmesi, sürecin yönetiminde aktörler arası işbirliği ve eşgüdüm olması, aktörlerin sorumluluk alanlarının belirlenmesi, alınan tedbirlerde ölçülü davranılarak istisnai koşulların düzenlenmesi bu sürecin yürütülmesinde gözetilen ilkeler olmuştur. Toplumsal yaşamı felce uğratan, devletlerin sınırlarını kapatmasına ve şehirlerin karantina altına alınmasına yol açan, sağllk altyapısı başta olmak üzere ekonomik yapıları alt üst eden, etkileri henüz tam olarak ölçülmese de derin olacağı varsayılan bu salgın sürecinde Türkiye'nin deneyimi ve mücadelesinin gelecekte karşılaşılabilecek riskler karşısında uygulanacak olan politikaların belirlenmesinde bir model olabileceği varsayılmaktadır. Literatür taraması yöntemiyle, güncel veriler ve kaynaklar taranarak hazırlanan çalışma giriş ve sonuç bölümleri dışında üç başlık halinde kurgulanmıştır.

\section{ABSTRACT}

This article is about Turkey's fight through the analysis of the policies and actors against the deadly COVID19 outbreak, which appeared in China in December 2019 and soon spread over to the global level. Fighting against the epidemic, a biological type of disaster inspired by approaches that characterize today's societies as risk societies with uncertainties; firstly, it is associated with the concepts of Risk Management and Crisis Management, which are two important elements of Disaster Management Process then Turkey's policies, which coincide with both phases, are evaluated in stages within the process approach from public policy approaches. The aim of the study is to evaluate the preparedness plan and health infrastructure assessed within the scope of Turkey's risk management process and within the scope of the precaution strategy adopted during the crisis management phase in response to the outbreak, social awareness, reduction of social mobility, limiting the transportation and circulation, economic regulations, progressive social solidarity to address normalization processes. Informing society especially with the principles of openness 
and transparency, determine the Evidence-Based policies, establish the cooperation and coordination between the actors in the management process, identify the area of responsibility of the actors, regulate the exceptional conditions in the execution of the precaution have been principles that are taken in this process. It is assumed that Turkey's experience and fight may be a model for determining the policies that will be implemented in the face of future risks during this epidemic which crippling the social life, led to a quarantine of the cities and closure the borders of the states, turn the economic structures especially health infrastructure upside down and although not yet fully measured the effects but assumed will be deep. The study, which was prepared by scanning the current data and sources with the method of literature search, was organized into three headings, except the introduction and conclusion sections.

“Hiçbir Virüs Alacağımız Tedbirlerden Daha Güçlü Değildir, Sorun Küresel, Mücadelemiz Ulusal”

\section{GİRIŞ}

Tarih boyunca insanoğlu çok sayıda doğal ve doğal olmayan felaketler ile karşı karşıya kalmış ve o günkü gelişmişlik düzeyi elverdiği ölçüde bunlarla başa çıkmaya çalışmıştır. İnsanoğlu ile doğa arasındaki ilişki çok yönlü ve karmaşık nitelikler taşımaktadır. Günümüze değin insan-doğa ilişkisi insanın doğayı denetim altına alma mücadelesi şeklinde sürdürülmüş sanayi devrimi ile birlikte bu ilişki, doğanın büyük bir tahribata uğramasına yol açmıştır. Nitekim günümüzde iklim değişikliği başta olmak üzere, ozon tabakasının incelmesi, ormanların tahribatı, çölleşme, biyolojik çeşitliliğin azalması, nükleer enerji kazaları, savaşlar, kıtlık, afetler, salgınlar gibi çok önemli çevresel sorunlar ortaya çıkmış ve bu sorunların çözümüne yönelik küresel düzeyde örgütlenmiş olan aktörler aracılığıyla önlemler alınmaya çalışılmıştır. Bütün bunlar çevre politikasındaki çok önemli bir ilkeyi hatırlatmaktadır. Çevre sorunları yerel düzeyde ortaya çıkmakla birlikte etkileri bölgesel, ulusal ve küresel düzeyde olabilmektedir.

İnsan toplumlarının günümüzde erişmiş olduğu gelişmişlik düzeyi bu sorunların üstesinden gelebilecek belirli bir aşamaya ulaşmışsa da özellikle doğal afetler gibi sorunlarla mücadelesi daha çetin olabilmektedir. Bu açıdan deprem, sel, volkanik patlamalar ve salgınlarda risk faktörleri çok boyutlu olduğu için risk yönetimi sürecinde sorunlar ortaya çıkabilmekte, afetin kontrol altına alınma süreci zaman alabilmektedir. Günümüz toplumunu risk toplumu olarak nitelendiren Ulrich Beck'in (1986) haklı olarak belirtmiş olduğu üzere geleneksel ve modern toplumlara göre karşı karşıya kalmış olduğumuz riskler farklı nitelikler taşımaktadır. Aslında öncesinde Knight (1921), Risk, Uncertanity and Profit (Risk, Belirsizlik ve Kar) adlı çalışmasında iktisat teorisi içinden risk ve belirsizlik konularını ele almıştır. Bu çalışmada Knight, içinde yaşadığımız dünyanın değiştiğini ve belirsizlikler içerdiğini, gelecek hakkında çok az şey bilebildiğimizi belirtmekte, riskin ölçülebilir olduğu halde belirsizliğin ölçülemeyeceğini belirtmektedir. İktisadi yaklaşımlara ilişkin bu tartışmanın dışında risk olgusu daha önce de ifade edildiği üzere Ulrich Beck tarafından risk toplumu kavramsallaştırmasıyla büyük bir yankı uyandırmıştır. Beck, F. Knight'in risk ve belirsizlik kavramları arasındaki farka değinmeyerek belirsizliği risk unsurlarından biri olarak değerlendirmiştir. Dolayısıyla bu tür süreçlerde riskin unsurlarından biri olan belirsizlikle başa çıkmak gittikçe daha fazla önemli hale gelmektedir. Nitekim Aven ve Renn (2018:230), nükleer tehlikeler, iklim değişikliği, salgın hastalıklar, yer sarsıntıları ve terör saldırılarını bu belirsizlikler arasında saymaktadır.

Dünya Sağlık Örgütü'nün (DSÖ) 11 Mart 2020'de pandemi ${ }^{1}$ ilan ettiği ve 2019 yılının son günlerinde Çin'in Hubei eyaletinin Vuhan kentinde ortaya çıkan ve bütün dünyayı sarsan KOVID-19 (Koronovirüs Hastalığı) salgını sürecinde yaşanan gelişmelerin risk toplumu ve onun içerdiği belirsizlik kavramıyla ilişkilendirilmesi salgının analizi açısından kolaylaştırıcı bir unsur olacaktır.

1 Dünya Sağlık Örgütü'ne göre pandemi, yeni bir hastalığın dünya genelinde yayılmasıdır (https://www.who.int/csr/disease/swineflu/frequently_asked_questions/pandemic/en/ Erişim tarihi: 03.04.2020). 
Çalışmada öncelikle KOVID-19 salgını, risk türlerinden biri olarak değerlendirildiği için risk, risk toplumu, risk yönetimi ve kriz yönetimi kavramsal çerçevede ele alınmıştır. Risk yönetimi ancak iyi tanımlanabilirse ardından gelen kriz yönetimi başarıya ulaşabilecektir. Bu gerçekten hareketle kriz yönetimi süreci başlamadan risk yönetimi sürecinin temellerinin atılmış olduğu söylenebilir.

Çalışma iki ana eksen etrafında hazırlanmıştır: Risk yönetimi süreci ve kriz yönetimi süreci. Bu iki başl1k altında Türkiye'nin pandemi ile mücadele süreci, tüm adımlarıyla belirli bir kronoloji ekseninde ortaya koyulurken kamu politikası aktörlerinin çok yönlü olarak süreç içerisindeki rolleri de analiz edilmiştir. Alınan isabetli eylemlerin yanı sıra tartışmalı kararlar, eksik veya zayıf görünen uygulamalara da tüm yönleriyle değinilmeye çalışılmıştır. $\mathrm{Bu}$ yönüyle çalışmanın gelecek araştırmacılar için çok yönlü veri sunması beklenmektedir.

Pandemi ile mücadele süreci incelenirken geliştirilen kamu politikası süreci, Pandemik İnfluenza Ulusal Hazırlık Planı çerçevesinde Türkiye'ye özgü bir yaklaşımla ele alınmıştır. Çalışmada bu yaklaşım kamu plitikası süreciyle ilişkilendirilerek, risk yönetimi ve kriz yönetimi sürecinin kamu politikası analizi ve yaklaşımları ile ilişkisi tespit edilmeye çalışılmış ve nihayetinde salgın sürecinde izlenen politikalar, toplumsal bilinçlendirme, ulaşım ve dolaşımın kısıtlanması, ekonomik önlemler ve düzenlemeler, sosyal yardım ve toplumsal dayanışmanın güçlendirilmesi gibi alt başlıklar halinde detaylandırılmıştır.

Çalışma ile amaçlanan, bir kamu politikası örneği olan Türkiye pandemi mücadelesi strateji ve yol haritasının çok yönlü olarak ortaya konulması ve elde edilen bulgularla ileriye dönük çalışmalar için emsal teşkil edebilecek kurgunun oluşturulmasıdır.

Çalışmanın önemli kısıtlarından bir tanesi pandemic ile mücadele sürecinin, çalışmanın hazırlandığı günlerde devam ediyor olmasıdır. Bu nedenle, çalışmanın amacına yönelik yeterli verilerin elde edildiğinin düşünüldüğü aşamada, çalışmanın sonlandırılmasına ve dinamik bir süreç olduğu gerçeği göz önüne alınarak karar verilmiştir. Veriler özellikle Cumhurbaşkanlığı, İletişim Başkanlığı, Sağlk Bakanlığı, İçişleri Bakanlığı vb. Kurumların web-internet sitelerinden edinilmiştir. Açıkça belirtmek gerekir ki, kapsamlı bir kamu politika analizinin izleme ve değerlendirme aşamalarının da ortaya konulabilmesi için sürecin tamamlanması, tüm verilerin elde edilmesi ve akabinde gözlem ve izleme aşamaları için uzunca bir zaman dilimi gerekmektedir. Bu nedenle, çalışmanın kapsamı, başlangıç olarak yol haritasının, kamu politikası aktörleri ve rollerinin, yönetsel sürecin risk yönetimi ve kriz yönetimi perspektifinde ele alınması ve Türkiye'ye özel bir kurgunun ortaya konulmasıdır. $\mathrm{Bu}$ yönüyle çalışmanın benzer konularda ileride gerçekleştirilecek bütünsel kamu politikası analizleri için altl1k oluşturacağ düşünülmektedir.

\section{SALGINLAR, RİSK TOPLUMU, RİSK, RİSK YÖNETIMİ, KRİZ VE KRİZ YÖNETIMİ}

Gripten vebaya, koleradan tifoya, AIDS’ten çiçek hastalığına insanoğlu tarih boyunca birçok salgın türüyle karşılaşmıştır. Bu salgınların önemli bir kısmı ortaya çıktığı yerin dışındaki diğer bölgeleri de etkilemiş olduğu için çok sayıda can kaybına yol açmış ve derin izler bırakmıştır.

Pamuk (2020), Milattan Sonra 6. yüzyılda başlayan, 8. yüzyıla kadar süren Jüstinyen Vebası'nı, 14. yüzyılın ortalarında başlayan ve 19. yüzyılın ikinci çeyreğine kadar tekrarlanan Kara Vebanın ve Birinci Dünya Savaşının son yılında başlayarak tüm dünyaya yayılan İspanyol Gribinin, Doğu Akdeniz-Orta Doğu bölgesini de etkisine alan üç önemli salgın olarak öne çıktığını ve her birinin on milyonlarca kişinin ölümüne yol açtığını belirtmektedir.

Aşağıdaki tabloda görüleceği üzere kimi kısa kimi de uzun süren ama her seferinde çok sayıda can kaybına yol açan salgın hastalıklar ortaya çıkmış ve insanoğlu da buna karşı tedbirler almaya ve bunların üstesinden gelmeye çalışmışıı. Salgınlar insan toplumlarında can kaybının dışında ekonomik, yönetsel, toplumsal ve siyasal anlamda çok önemli değişimler yaşanmasına yol açmıştır. Salgın hastalıklar Osmanlı ve Cumhuriyet Türkiye'si dönemlerinde de yaşanmış ve dönemin yönetimleri o günkü koşullar dahilinde salgın sürecini yönetmeye çalışmışlardır².

2 Osmanlı döneminde yaşanan salgınlar ve salgınlarla mücadele konusunda yapılan çalışmalar hakkında ayrıntılı bir kaynak için Bkz.: Başağaoğlu vd., 2015. 
Tablo 1. Dünya Tarihinde Yaşanan Önemli Salgınlar

\begin{tabular}{|c|c|c|c|}
\hline Salgın & Zaman Dilimi & Tip/Çıkış Kaynağı & Tahmini Ölüm Sayısı \\
\hline Antonine Salgını & $165-180$ & Çiçek veya Kızamık (öngörülen) & 5 milyon \\
\hline Justinian Vebası (1. Veba Salgını) & $541-542$ & Yersinia pestis bakterisi/Fare, Pire & 30-50 milyon \\
\hline Japonya Çiçek Salgını & $735-737$ & Variola majör virüsü & 1 milyon \\
\hline Kara Veba & $1347-1351$ & Yersinia pestis bakterisi/Fare, Pire & 200 milyon \\
\hline Yeni Dünya Çiçek Salgını & 1520 ve sonras 1 & Variola majör virüsü & 56 milyon \\
\hline İtalyan Vebası & $1629-1631$ & Yersinia pestis bakterisi/ Fare, Pire & 1 milyon \\
\hline Londra Büyük Vebası & 1665 & Yersinia pestis bakterisi & 100 bin \\
\hline Kolera Pandemileri (1-6) & $1817-1923$ & V. cholera bakterisi & 1 milyondan fazla \\
\hline Üçüncü Veba Salgını & 1885 & Yersinia pestis bakterisi/Fare, Pire & 12 milyon \\
\hline Sarı Humma & 1880'lerin Sonu & Virüs/Sivrisinekler & 100-150 bin \\
\hline Rus Gribi & $1889-1890$ & $\mathrm{H} 2 \mathrm{~N} 2$ virüs & 1 milyon \\
\hline İspanyol Gribi & 1918-1919 & H1N1 virüs/Domuz & 40-50 milyon \\
\hline Asya Gribi & $1957-1958$ & $\mathrm{H} 2 \mathrm{~N} 2$ virüs & 1.1 milyon \\
\hline Hong Kong Gribi & $1968-1970$ & $\mathrm{H} 3 \mathrm{~N} 2$ virüs & 1 milyon \\
\hline HIV/AIDS & 1981-günümüz & Virüs /Şempanze & 25-35 milyon \\
\hline SARS & $2002-2003$ & Koronavirüs/Yarasa,VahşiKedi & 770 bin \\
\hline Domuz Gribi & $2009-2010$ & H1N1 virüs /Domuz & 200 bin \\
\hline Ebola & 2014-2016 & Ebolavirüs /Vahşi Hayvanlar & 11 bin \\
\hline MERS & 2015-günümüz & Koronavirüs/Yarasa,Deve & 850 bin \\
\hline COVID-19 & 2019-günümüz & Koronavirüs/(muhtemelen) Pangolin ${ }^{3}$ & 175 bin $807^{4}$ \\
\hline
\end{tabular}

Kaynak: LePan, 2020, https://www.visualcapitalist.com

Geçmişte yaşanan salgınların günümüzdeki salgınlardan en önemli farkı insan hareketliliğinin geçmişe oranla daha fazla artmış olmasından kaynaklanan yüksek yayılma ve bulaşma hızı oluşmuştur. Küreselleşme sürecinin sonuçlarından biri olan yüksek hareketlilik bir anda Çin’de ortaya çıkan hastalığın dünyanın birçok ülkesine yayılmasına neden olmuş, devletler sınırlarını kapatmış, ülkeler ve şehirler karantinaya alınmış, insanlar evlerine çekilmiş, hayat adeta durmuştur. İlk vakanın 1 Aralık 2019'da açıklanmasıyla başlayan süreç hızlı vaka artışlarıyla ilerlemiş ve 2020 yılının Nisan ayı sonu itibariyle dünya genelinde ciddi sayılara ulaşmıştır. Küreselleşme ile gelen hızlı yayılma sonucu ortaya çıkan veriler sırasıyla Şekil 1 ve Şekil 2'de görülebilmektedir.

3 Pangolin, karınca, termit ve larvalar ile beslenen, genellikle "pullu karıncayiyen" olarak bilinen memeli bir hayvandır, https://www.worldwildlife.org

4 Dünya Sağlık Örgütü verilerine göre 23.04.2020 itibariyle bildirilen toplam ölüm vaka sayıs1, https://covid19.who.int/ 


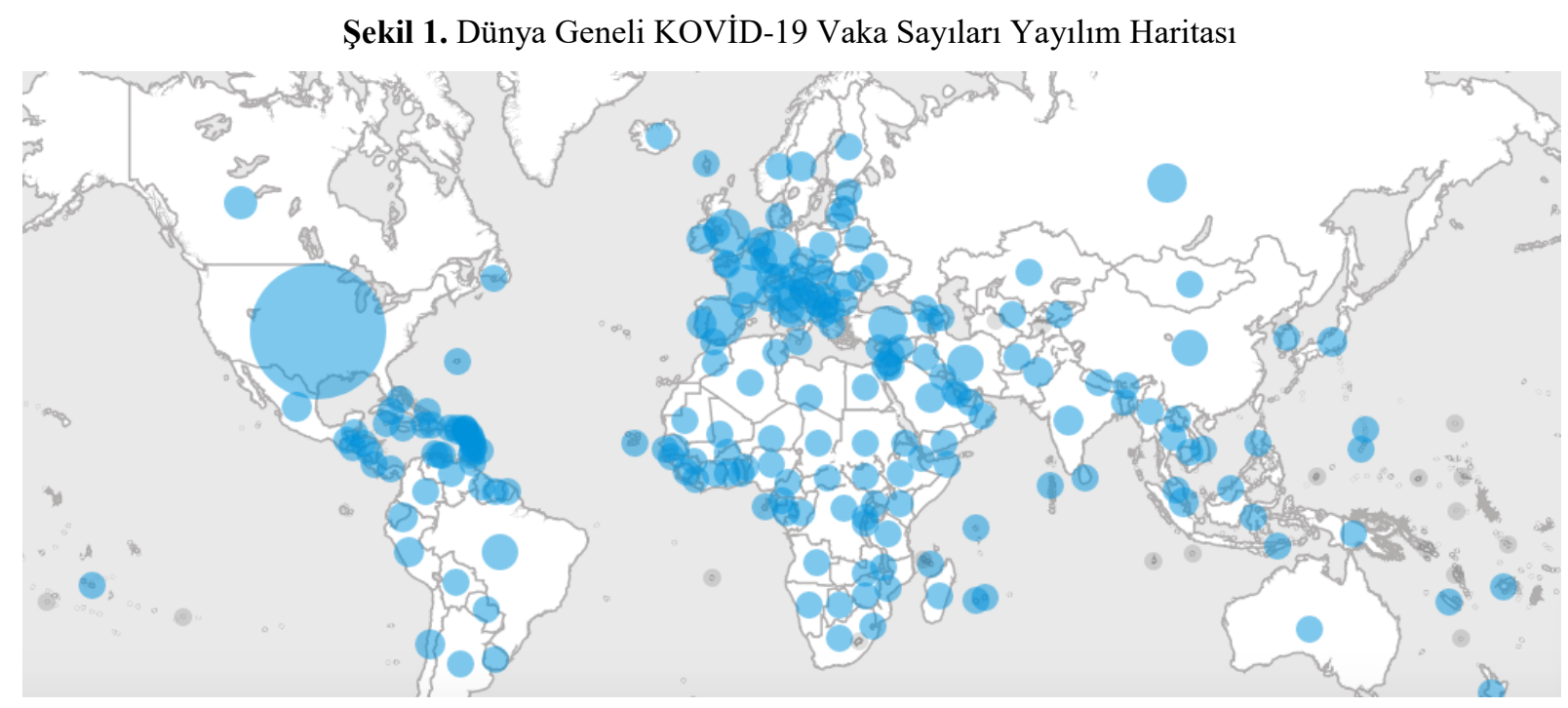

Kaynak: Dünya Sağl1k Örgütü, https://covid19.who.int/ (Erişim Tarihi: 23.04.2020).

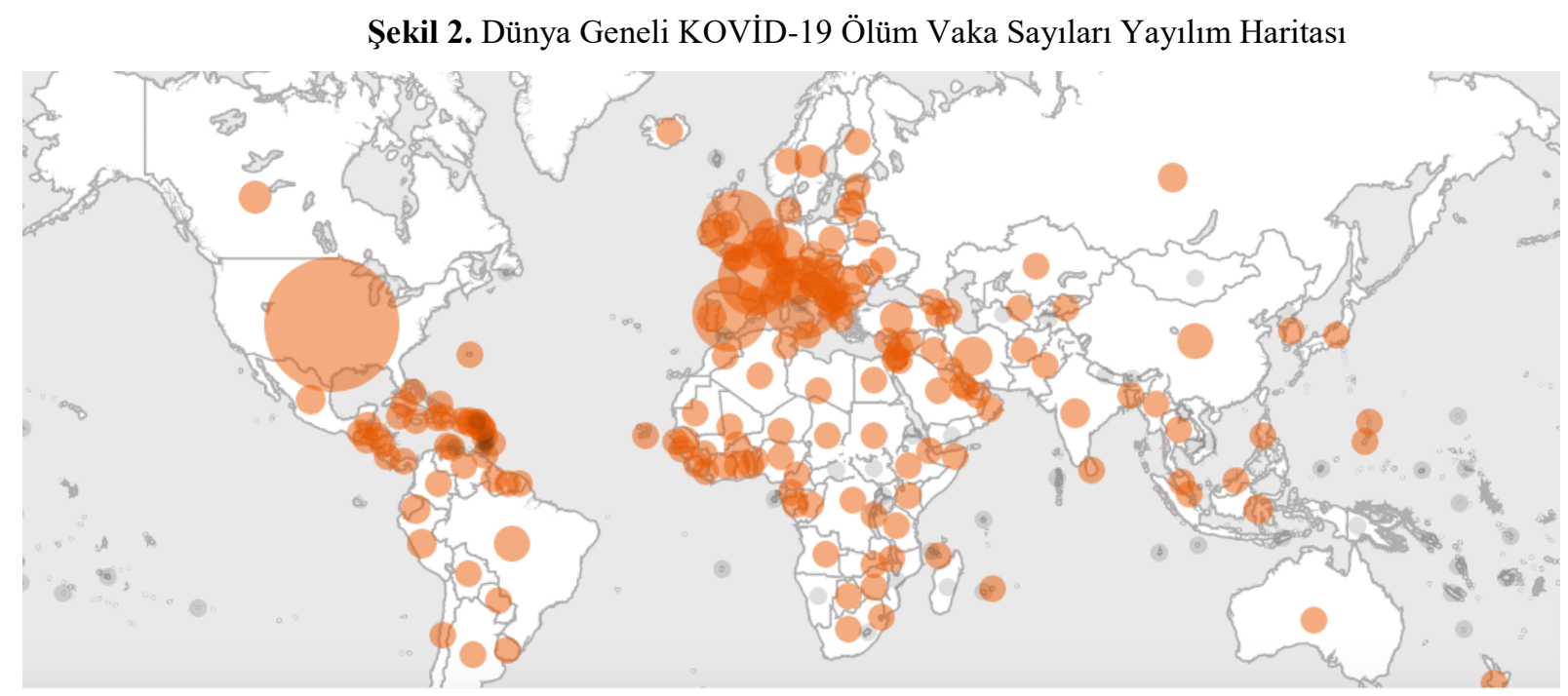

Kaynak: Dünya Sağlık Örgütü, https://covid19.who.int/ (Erişim Tarihi: 23.04.2020)

Tablo 2'de ise benzer veriler Türkiye ile karşılaştırmalı olarak yer almaktadır.

Tablo 2. Dünya Geneli ve Türkiye KOVID-19 Vaka Durumu ${ }^{5}$

\begin{tabular}{|c|c|c|}
\hline KOVID-19 VAKA DURUMU & DÜNYA GENELI & TÜRKIYE \\
\hline Vaka sayısı & $2,549,610$ & 98,674 \\
\hline Ölümlü vaka sayıs1 & 175,807 & 2,376 \\
\hline
\end{tabular}

Kaynak: Dünya Sağlık Örgütü (https://covid19.who.int/)

Dünya Sağlık Örgütü tarafından 3,595,662 kesinleşmiş vaka ve 247,652 ölüm vakas1 rapor edilmiştir. En çok vaka 1,593,828 ile Avrupa yakasında görülürken onu Amerika kıtası 1,507,148 olarak takip etmektedir. Afrika kıtas1 33,973 vaka ile en az etkilenen coğrafya olarak gözükse de ilerleyen günlerde ciddi yayılma beklenmektedir (https://covid19.who.int/, 2020). 
TURAN, Abdulmenaf ve ÇELIKKYAY, Hicran HAMZA - Türkiye'de KOVİD-19 ile Mücadele: Politikalar ve Aktörler

KOVIDD-19 salgını Amerika Birleşik Devletleri, Çin, Birleşik Krallık, Almanya, Fransa, İtalya, Japonya gibi üst sıralardaki dünya ekonomilerini neredeyse çökme noktasına getirmiştir. Sadece son bir hafta içinde 6.6 milyon kişinin işsiz kaldığı açıklanmıştır. Ayrıca şimdilik 80 ülke Uluslararası Para Fonu'ndan (IMF International Monetary Fund) finansal destek talep etmiştir. Ekonomik Kalkınma ve İşbirliği Teşkilatı (OECD Organization for Economic Cooperation and Development) ise virüsün yayılımının devam etmesi durumunda 2020 y1lı için küresel büyümenin \%1.5 oranında azalacağını açıklamıştır (Mahar, 2020) bazı kaynaklara göre ise bu oranın \%3'ten \%2.4'e düşeceği ve küresel büyümedeki sadece \%0.4'lük olan bu düşüşün, yaklaşık 3.5 trilyon $\mathrm{ABD}$ doları kayıp anlamına geldiği ifade edilmektedir (Duffin, 2020). Bu ve benzeri süreçleri anlamlandırmak üzere geliştirilmiş olan risk toplumu kavramı küreselleşmenin bu yönünün anlaşılmasını kolaylaştırmıştır. Bundan ötürü öncelikle risk toplumu kavramı Ulrich Beck (1986) ve Antony Giddens'in (1999) çalışmalarından yararlanılarak değerlendirilecek, sonrasında risk, risk yönetimi, kriz ve kriz yönetimi kavramları tanımlanacaktır.

Beck (1986:25-29), adı geçen çalışmasında, günümüzdeki tehlikelerin temelinde sanayideki aşırı üretimin olduğunu, riskler ve tehlikelerin tehdidin küresel doğası ve modern sebeplerinden ötürü yüzeysel olarak benzemekle birlikte, Ortaçağ' daki risk ve tehlikelerden ayrıldığını ve bunların modernleşmeden kaynaklanan riskler olduğunu belirtmektedir. Devamla bu risklerin oluşturdukaları etkiler bakımından artık doğdukları yerde kalmadıklarını, doğası gereği gezegendeki her türlü yaşam formunu tehlikeye attığını ifade ederek risk toplumunda bilinmeyen kasıtsız sonuçların belirgin hale geldiğini vurgulamaktadır. Bununla beraber Beck, riskle karşı karşıya kalmış bir toplumunun felaket toplumu olduğunu, dünya risk toplumuna doğru gidildiğini ve bu toplumda olağanüstü halin normal durumu dönüşme tehlikesi taşıdığını söylemektedir.

Giddens (1999), benzer bir yaklaşımla önce geleneksel toplumlarla modern toplumları risk olgusu üzerinden karşılaştırarak aradaki farklılıkları ortaya koymaktadır. Ona göre, asıl farklılık günümüz toplumlarındaki risklerin önceki toplumlardaki risklerden daha fazla olmadığı, ancak risk ile tehlike arasındaki dengesizliğin artmış olmasıdır. Devamında, kendi üretmiş olduğumuz tehlikelerin dışarıdan gelen tehlikelerden daha fazla tehdit içerdiğini, bir kısmının bizleri bireysel olarak etkilediğini ancak küresel ekolojik sorunlar, nükleer silahların yayılması, dünya ekonomisinin çökmesi gibi risklerin asıl felaketler olduğunun altını çizerek risklerin birçok bilinmezlik/belirsizlik içerdiğini belirtmektedir. Her iki düşünürün de (Beck ve Giddens) üzerinde durduğu temel konu risklerin küresel bir nitelik taşıdığıdır. KOVID-19 salgını da küresel bir risk haline gelmiş olduğu için salgının risk toplumuna özgü bir nitelik taşıdığı belirtilebilir.

Fransızca kökenli risque sözcüğü ile Türkçe'de karş1lı bulan risk Türk Dil Kurumu (TDK) Sözlüğüne göre "zarara uğrama tehlikesi" olarak anlam kazanmıştır. Yine TDK İktisat Terimleri Sözlügünde risk; "iktisadi karar birimlerinin verecekleri kararlar sonucunda ortaya çıkacak getiriyi olumsuz etkileyebilecek olayların gerçekleşme olasılığı, diğer bir deyişle olayların gerçekleşme olasıllı̆̆ını bilindiği durum, belirsizlik", olarak ifade edilmektedir. Aynı sözlüğe göre, risk yönetimi, "kurum veya işletmelerin çalışmalarını gerçekleştirirken oluşabilecek risklerin önceden dikkatli ve ayrıntılı bir biçimde tanımlanıp değerlendirilmesi, riskleri ortadan kaldıracak veya en aza indirecek önlemlerin alınması süreci" olarak tarif edilmiştir. İktisat Terimleri Sözlüğünde ise risk yönetimi, "riskin tanımlanması, çözümlenmesi, değerlendirilmesi ve izlenmesini sağlamayl, riskleri azaltmak için gerekli önlemleri almayı içeren yönetim politikalart ile izlenecek yöntem ve uygulamalar bütünü’dür.

TDK Sözlüğüne göre kriz; "bir ülkede veya ülkeler arasında, toplumun veya bir kuruluşun yaşamında görülen güç dönem, bunalım, buhran", olarak tanımlanırken kriz yönetimi; "bir ülkenin karşılaştı̆̆ ulusal, uluslararası herhangi bir sorun veya doğal afet durumlarında sorunun en az zararla atlatılabilmesi için konunun uzmanlarından oluşturulan kurul" veya "bir ülkenin karşılaştı̆̆ ulusal, uluslararası herhangi bir sorun veya doğal afet durumunda sorunun en az zararla atlatılabilmesi için gerekli kararların alınmast işi”" şeklinde ifade edilmiş̧tir (www.tdk.gov.tr). Bu tanımlar birlikte değerlendirildiğinde riskin krizden önce risk yönetiminin de kriz yönetiminden önce olması gerektiği sonucuna varılmaktadır. Şekil 3'te risk, risk yönetimi, kriz ve kriz yönetimi ilişkisel döngüsü gösterilmektedir. 
Şekil 3. Risk, Risk Yönetimi, Kriz ve Kriz Yönetimi İlişkisel Döngüsü

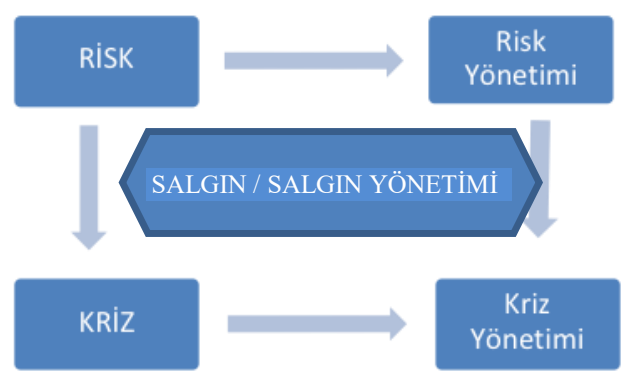

Şekil 3’te görüldüğü üzere, risk yönetimi ve kriz yönetimi süreçleri arasında salgın yönetimi açısından ilişkisel bir döngü bulunmaktadır. Dolayısıyla, risk faktörleri ne kadar azaltılırsa ve olasılıklar ne denli iyi tahmin edilirse, ileriye dönük projeksiyonların belirlenmesinde ne oranda isabet ettirilebilirse, riskleri azaltmak için ne denli önlemler alınıp ona uygun politikalar geliştirilirse krizler ortaya çıktığı andan itibaren de o oranda etkin bir kriz yönetimi süreci sergilenmiş olacaktır. Özellikle afet yönetimi süreci ile ilişkilendirildiğinde risk yönetimi ve kriz yönetimi daha iyi kavramsallaştırılabilecektir.

Afet yönetimi sürecinde afet öncesi dönem risk yönetimi, afet anı ve afet sonrası dönem ise kriz yönetimi aşaması şeklinde gösterilmektedir. Kuşkusuz bu kavramsallaştırmada afetlerin yaygın etkisi ve bundan kaynaklanan bir deneyimin sağlamış olduğu olanaklar söz konusudur. Bir afet türü olarak salgınlar da depremler kadar insan toplumlarını etkilemiş, çok sayıda can kaybına yol açmıştır. Ancak salgınların risk yönetimi ve kriz yönetimi şeklinde depremler gibi aşamalar halinde gösterilmesi kolay olmamakla birlikte bu çalışmada bunun deneneceğini belirtmek gerekir. Şekil 4'te afet yönetim aşamaları gösterilmektedir.

Şekil 4. Afet Yönetim Aşamaları

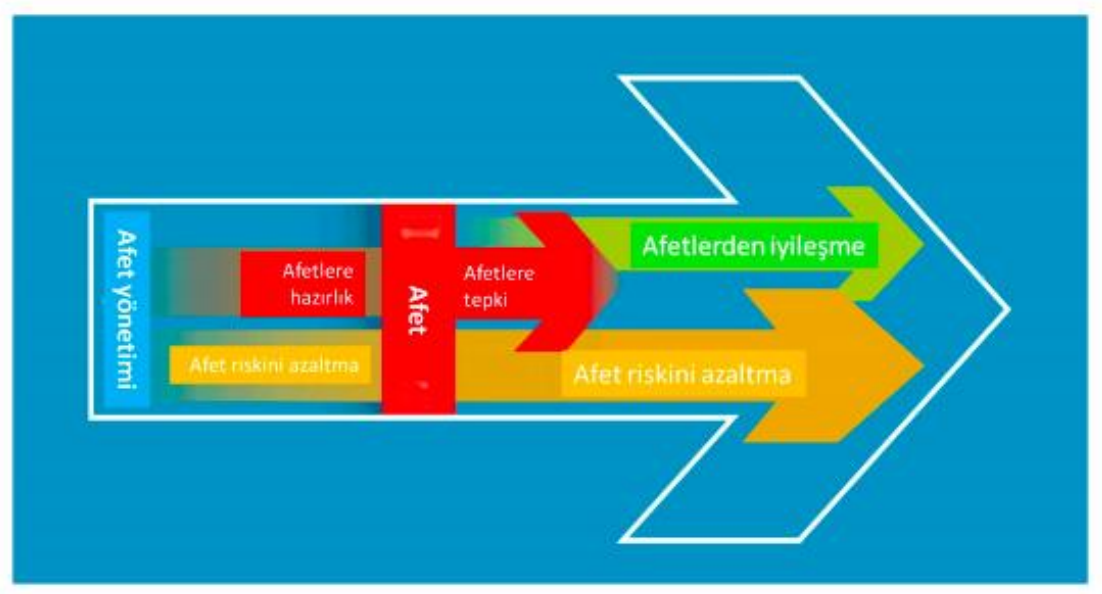

Kaynak: Gökçekuş vd., 2018:20.

Afet yönetimi açısından, salgınlar, biyolojik afetler arasında "pandemik felaketler" kategorisinde incelenmektedir. Biyolojik afetler, organik kaynaklı veya biyolojik taşıyıcılar nedeniyle ortaya çıkan olgular olarak tarif edilmektedir. Bu biyolojik taşıyıcılar, hastalık taşıyan mikroplar, virüsler, toksinler ve bio-aktif ürünler olabilir. Buna örnek olarak salgın hastalıklar, hayvan ve bitkilerdeki salgın hastalıklar, böcek veya diğer hayvan istilaları verilebilir (Güngör, t.y.). Bir çeşit afet olarak kabul edilen salgınlar, afet yönetimi açısından müdahale önceliği olarak farkındalık oluşturmak, uygulamaya geçmek, gönüllü faaliyetlere dayalı sosyal seferberlik oluşturmak ve lojistik destek sağlamak olarak ifade edilmektedir (Gökçekuş vd., 2018:12). Sağl1k alanında yapılan çalışmalar, geleneksel olarak afetlere ve acil durumlara müdahale üzerine odaklanmıştır. Bununla birlikte son yıllarda, zararları önleme ve riskleri azaltma yönündeki çalışmalar afetlerle ilişkili sağlık riski ile mücadelede daha verimli bir yaklaşım olarak kabul edilmektedir (Chan ve Shaw, 2020: v).

Dünya genelinde KOVID-19 hızla ve benzeri görülmemiş bir şekilde sağlik, ekonomik ve jeopolitik bir krize dönüşmüştür. Krizin üstesinden gelinmesi birçok küresel (aynı zamanda yerel) politikanın entegrasyonunun 
TURAN, Abdulmenaf ve ÇELİKYAY, Hicran HAMZA - Türkiye'de KOVİD-19 ile Mücadele: Politikalar ve Aktörler

hızlandırılması zorunluluğunu da beraberinde getirmiştir (Djalante vd., 2020:2). 2015 yılında gerçekleştirilen Birleşmiş Milletler Üçüncü Afet Riski Azaltma Konferansı'nda kabul edilen Sendai Afet Riskini Azaltma Çerçevesi, bu bağlamda kazanımların afet riskinden korunması için devletlere somut öneriler getirmektedir. Çerçevede, "afet riskinin azaltılması ile kişilerin, kurumların, toplulukların ve ülkelerin ekonomik, fiziksel, sosyal, kültürel ve çevresel varlıklarındaki kayıplarının önemli ölçüde azaltılacağı" deklare edilmiştir (UNDRR, 2015).

Chan ve Shaw, ${ }^{6}$ Sendai Afet Riski Azaltma Çerçevesi'ne özel bir atıfta bulunarak afet riskinin azaltılması hedefiyle yapılan anlaşmalar arasında bunun dönüm noktası olduğunu belirtmektedir (Djalante vd., 2020:2). Afete hazırlıklı olma ve toplum temelli sağlık sisteminin dirençli hale getirilmesi, afetlerin etkisinin azaltılması ve zararların önlenmesi açısından mücadelede rol alacak tüm paydaşların birçok farklı sektörden seçilmeleri ve bunların koordinasyonu hayati öneme sahiptir. Dolayısıyla, salgınlar ile mücadele detaylı, bütüncül ve çok paydaşlı pandemik bir plan gerektirmektedir. Sağlık Bakanlığı tarafından hazırlanan Pandemik Influenza Ulusal Hazırlık Planı da tüm bu ilkeleri gözetecek şekilde hazırlanmıştır. Konuyla ilgili birçok kamu ve özel sektör kademesinden uzman, politik gelişim, mevzuat/kanun hazırlama, hayvan sağlığ 1 , halk sağlı̆g , hasta bakımı, laboratuvar tanısı, aşı ve ilaç, tedariki, iletişim ve afet yönetimi gibi konularla ilgilerinden dolayı mücadeleye dahil edilmişlerdir. Planda, Afet ve Acil Durum Yönetimi Başkanlığı ve İl AFAD Müdürlüğü gibi kurumlara risk azaltma, hazırlık, müdahale ve iyileştirme çalışmalarında destek olunması konularında görev verildiği görülmektedir (Pandemik İnfluenza Ulusal Hazırlık Plan1, 2019:5,52-65).

Salgınlar afet türlerinden daha doğrusu biyolojik afetlerden biri olarak kabul edilmekte olduğu için risk yönetimi ve kriz yönetimi aşamaları benzerlik taşımaktadır. Hatta "ciddi salgınların kendileri de bir afet olmalarına rağmen, kimi zaman diğer afetlerden sonra da önemli salgınlar ortaya çıkabilmektedir" (Güler ve Çobanoğlu, 1994:17).

Kamu kurum ve kuruluşlarının kamu yönetimi alanındaki geçmiş krizlere nasıl tepki verdiklerine dair araştırmalar, mevcut ve gelecekteki krizlere gösterecekleri tepki ve dayanıklılık dereceleri hakkında ipuçlanı sunabilir (Robinson ve Wehde, 2020). Ancak her bir afet türünde afet yönetimi süreci farklılıklar göstermektedir. Haluk Eyidoğan'ın (2020), saptamış olduğu üzere;

"Bu virüs saldirisı bir deprem, tayfun, sel, savaş ve terör gibi değildir. Bu afet ne zaman biter ve herkes normal hayatına ne zaman döner bilemiyoruz, ancak salgin hastalıklarla ilgili mücadele altyaplsl, strateji ve eylem planları dahil afet yönetim sistemi yerelde ve dünyada bu afetten sonra yeniden gözden geçirilecektir. Sinır ve coğrafya dinlemeyen bu virüs salgını doğal afet olarak sinıflanabilir ama insan hataları, yetersiz önlemler ve insandan insana bulaşma nedeniyle insan kaynaklı bir afete dönüşmüşü̈r. Diğer bir deyişle "hibrit afet” kimliği kazanmıştır".

Tablo 3'te afet türleri yer almaktadır.

Tablo 3. Dünyada Gözlenen Afet Türleri

\begin{tabular}{|c|c|c|c|c|}
\hline Jeolojik Afetler & Klimatik Afetler & Biyolojik Afetler & Sosyal Afetler & Teknolojik Afetler \\
\hline Deprem & Sıcak/Soğuk Dalgası & Erozyon & Yanginlar & Maden Kazaları \\
\hline Heyelan & Kuraklık & Orman Yangınları & Savaşlar & $\begin{array}{l}\text { Biyolojik, Nükleer, Kimyasal } \\
\text { Silahlar ve Kazalar }\end{array}$ \\
\hline Kaya Düşmesi & $\begin{array}{l}\text { Dolu, Çı̆̆g, Tipi, Sis, } \\
\text { Aşırı Kar Yağışları, Asit } \\
\text { Yağmurları, Buzlanma }\end{array}$ & Salgınlar & Terör Saldırıları & Sanayi Kazaları \\
\hline Volkanik Patlamalar & Hava Kirliliği & Böcek İstilas1 & Göçler & Ulaşım Kazaları \\
\hline $\begin{array}{l}\text { Çamur Akıntıları } \\
\text { Tsunami }\end{array}$ & $\begin{array}{l}\text { Hortum, Kasırga, } \\
\text { Tayfun, Tornado, Sel, } \\
\text { Siklonlar, Y1ldırım }\end{array}$ & & & \\
\hline
\end{tabular}

Kaynak: www.afad.gov.tr

Kabaca afet yönetimi bakımından risk yönetimi süreci "hazırlıkl olma" ve "risk azaltma" şeklinde iki aşama halinde ele alınmaktadır. Ancak kimi zaman afet yönetimi/yönetişimi bakımından risk yönetimi süreci, (1) risk

6 “Kamu Să̆lı̆̆ ve Afetler Acil Sağlık ve Afet Risk Yönetimi” başlıklı kitap, Sağlıkta Acil ve Afet Risk Yönetimi konusunu kapsamlı bir şekilde işleyen bir kitap olarak belirtilmektedir (Djalante vd., 2020:6). 
yönetimi açısından yönetsel altyapı ya da genel durum, (2) risk tanımlama, (3) risk azaltma, (4) afetlere hazırlık (5) afet sonrası iyileştirme planı ve (6) finansal koruma gibi aşamalar şeklinde ele alınmıştır (Lacambra vd., 2015). Benzer şekilde, Dünya Sağlık Örgütü (2019) tarafından yayınlanan Sağlık Acil Afet Risk Yönetimi (Health-EDRM) belgesinde, acil durumların ve afetlerin yol açtı̆̆ 1 sağlık risklerinin sistematik analizi ve yönetimi (1) riskleri önlemek ve azaltmak, (2) afetlere hazırlık, (3) müdahale ve (4) iyileştirme önlemleri olarak sıralanmıştır (Djalante vd., 2020:2 ve DSÖ, 2019). Örneğin domuz gribi vakasında risk yönetimi ve risk yönetişimi ile ilgili temel ilkeler şöyle sıralanmıştır (Aven ve Renn, 2018:230-231);

- Büyük belirsizlikler karşısında riskin tanımlanması.

- Karar vermede orant1l111k ve tutarl111k.

- Risk değerlendirmesi ve uyarıcı ve ihtiyati ilkeler gibi çeşitli yönetim yaklaşımları arasından seçim yapmak

- Risk yönetimi sürecinde risk algısı

- En uygun risk iletişimi

- Etkililik ve verimliliğe karşı açıklık ve şeffaflık ilkeleri.

$\mathrm{Bu}$ açıdan değerlendirildiğinde küresel düzeyde KOVID-19 salgınında "hazırlıkl olma" ve "risk azaltma" süreçlerinin etkin bir biçimde izlenmemiş olduğu sonucuna varılabilir. Kuşkusuz burada riskin hesaplanamaz, öngörülemez, çok boyutlu olma, hızlı yayılma ve yaygın olma özelliklerini göz önünde bulundurmak gerekmektedir. Dünyanın gelişmiş ülkeleri, 1999 depremlerinden sonra da Türkiye'nin afet öncesi sürece hazırlıklı olma ve risk azaltma aşamalarında önemli gelişmeler kaydetmiş olduklarını ve depremi en az hasarla atlatma aşamasına gelmiş olduklarını belirtmek gerekir. Ancak KOVID-19 benzeri salgınlarda az önce de belirtilmiş olduğu üzere bir anda bu sürecin yönetilmesi önemli güçlükler barındırmaktadır. Nitekim ortaya çıktığı andan itibaren bulaşma hızı, ölümcül olma düzeyi, küresel düzeyde yaygınlaşması risk faktörlerinin yeterince hesaplanamadığını göstermekle birlikte, sağlık altyapısı görece daha güçlü olan ülkelerin bu süreci kısmen de olsa daha iyi yönetebildiğini göstermektedir. Ancak genel anlamda neredeyse bütün devletlerin bu sürece hazırlıksız yakalanmış olduğu ifade edilebilir. Dolayısıyla küresel düzeyde etkin bir risk yönetimi sürecinin olmadığ 1 ve bundan kaynaklanan sorunların kriz yönetimi aşamasına taşındığı bir olguyla karşı karşıya kalındığı söylenebilir.

Risk yönetimi açısından izlenmesi gereken stratejiler birleştirildiğinde üç temel strateji öne çıkmaktadır (Aven ve Renn, 2018:32). Bunlar sırasıyla, risk değerlendirmeleri yaparak, kaçınma, risk azaltma, aktarım ve elde tutmayı içeren risk bilgilendirme, risk yönetimi yaklaşımını seçerken dikkatli olmayı, sağlamlık ve dayanıklılık, sürekli izleme, çevreleme, bilgiyi arttırmak için araştırmalar yapmayı içeren ihtiyatlı olma ve tedbir alma ve son olarak güven oluşturmak, gerçeklerin açıklığa kavuşturulması, belirsizliklerin azaltılması, etkilenenlerin katılımı, müzakere ve hesap verebilirlik gibi önlemlerin uygulanmasını içeren söylemsel stratejilerdir. Yine depremler başta olmak üzere "acil müdahale, arama-kurtarma, ilk yardım", "iyileştirme" ve "yeniden inşa" süreçlerini içeren kriz yönetiminin salgın açısından başka türlü tasnif edilmesi gerekmektedir. Nitekim bu süreçte genel olarak salgına yakalanmış olanlara müdahale, tedavi, salgının yayılmasını önleme, salgın sürecinde ekonomik, toplumsal, yönetsel alanlar başta olmak üzere çok boyutlu önlemler alınarak süreci iyileştirme aşamalarının izlendiğini belirtmek gerekir. Dolayısıyla salgın konusunda ana başlıklar olarak risk yönetimi ve kriz yönetimi süreçlerinin afet yönetimi sürecine benzediği ancak salgının doğası gereği müdahale etme biçimleri ve aşamalarının farklılaştığı görülmektedir. Tablo 4'te risk yönetimi ve kriz yönetimi süreçleri yer almaktadır.

Tablo 4. KOVİD-19 Salgını Risk Yönetimi ve Kriz Yönetimi Süreçleri

\begin{tabular}{|c|c|c|}
\hline Salgın Yönetimi & Aşamalar & Türkiye'de Uygulama Süreci \\
\hline \multirow{3}{*}{ Risk Yönetimi } & Hazırlıklı Olma & $\begin{array}{c}\text { Cumhurbaşkanlığı Hükümet Sistemi } \\
\text { Pandemik İnfluenza Ulusal Hazırlık Planı } \\
\text { Sağlık Altyapısı }\end{array}$ \\
\cline { 2 - 3 } & Risk Azaltma & $\begin{array}{c}\text { Sağlık Altyapısını Destekleyen Unsurlar } \\
\text { Bilim Kurulunun Kurulması }\end{array}$ \\
\hline \multirow{3}{*}{$\begin{array}{c}\text { Kriz Yönetimi } \\
\text { (Tedbir Stratejisi) }\end{array}$} & $\begin{array}{c}\text { Müdahale ve Yaygınlaşmasını } \\
\text { Önleme }\end{array}$ & $\begin{array}{c}\text { Toplumsal Bilinçlendirme Çalışmaları } \\
\text { Ulaşım ve Dolaşımın Kısıtlanması }\end{array}$ \\
\cline { 2 - 3 } & İyileştirme & $\begin{array}{c}\text { Ekonomik Önlemler ve Düzenlemeler } \\
\text { Sosyal Yardımlaşma ve Toplumsal Dayanışma }\end{array}$ \\
\cline { 2 - 3 } & Aşamalı Normalleşme & Kontrollü Sosyal Hayat \\
\hline
\end{tabular}




\section{SALGINDA RISKK YÖNETIMİ SÜRECI}

Bu konuyu ele alırken iki önemli noktayı dikkate almak gerekir: Türkiye'nin yönetsel yapısı ve salgınla ilişkili altyap1 olanakları. Türkiye, 24 Haziran 2018 tarihinde yapılan Cumhurbaşkanlığı ve Milletvekili Genel Seçimleri ile birlikte daha önce anayasal altyapısı hazırlanmış olan Cumhurbaşkanlığı Hükumet Sistemi'ne geçmiştir. Salgın süreci aslında bu yeni hükümet sisteminin uygulamaya nasıl yansıdığına ilişkin değerlendirmelere imkân sunmaktadır. Özellikle kriz yönetimi süreçlerinde karar alma mekanizmalarının hızlı işletilmesi, karar alma sürecinde eşgüdümün sağlanması, politika belirleme ve uygulamada etkinlik ve verimlilik ilkelerinin işletilmesi, toplumu bilgilendirme ve toplumsal bilinçlendirme çalışmalarında şeffaflığın sağlanması, toplumda güven duygusunun oluşması, güvenlik ve denetim imkânlarını kolaylaştırması bakımından avantajlar sunmaktadır. Ancak katılım ve yönetişim ilkelerinin kriz yönetimi sürecinin doğası gereği kimi zaman aksaması bir dezavantaj gibi görünmekle birlikte aslında ilgili toplumsal kesimlerin karar alma süreçlerine katılımı konusunda kimi olanaklar da sunulmaktadır. Bu açıdan değerlendirildiğinde risk yönetimi sürecindeki belirsizlik, çok boyutluluk, yaygın etki konusundaki olumsuzlukların kriz yönetimi sürecinde bertaraf edilmekte olduğu görülmektedir. Öte yandan Türkiye'nin sağlik yönetimi konusunda gerçekleştirmiş olduğu reformlar salgına hazırlık sürecini yönetmeyi kolaylaştırmıştır.

Hazırlıklı olma ve risk azaltma süreçleri bakımından Türkiye'nin genel anlamda kurmuş olduğu altyapı imkânları, salgının ortaya çıkmasıyla birlikte etkin müdahale etme imkânlarını kolaylaştırmıştır. Daha önce de belirtildiği üzere risk yönetimi sürecinde başarı kriz yönetimi sürecindeki başarıyı da etkilemektedir. Bu açıdan değerlendirildiğinde sağlık altyapısı ve insan kaynakları bakımından sahip olunan avantajlı konum, sürecin yönetimini olumlu etkilemiştir. Öte yandan henüz bu salgın ortaya çıkmadan Sağlık Bakanlığı Halk Sağlı̆̆1 Genel Müdürlüğü tarafından 2019 yılında hazırlanmış olan Pandemik İnfluenza Ulusal Hazırlık Planı odağında böylesi bir salgın durumunda gerçekleştirilecek olan faaliyetleri, yaygınlık düzeyleri, müdahale biçimleri gibi önemli konuları ele almıştır. Nitekim planda belirtildiği üzere daha önceki benzer salgınlardan yola çıkılarak bir müdahale senaryosu hazırlanmıştır. Bu çalışma bir bakıma hazırlıklı olma ve risk azaltma süreçlerini içeren risk yönetimi sürecine yönelik bir rehber olma özelliğine sahiptir. Adı geçen planda yer alan şu ifadeler risk yönetimi açısından önem taşımaktadır;

\section{"Detaylı ve bütüncül bir pandemik plan için çok paydaşl yaklaşım ve halkın katıllımına ihtiyaç duyulmaktadır. Çok paydaşlı yaklaşım; konuyla ilgili birçok kamu ve özel sektör kademesinden uzmanın, politik gelişim, mevzuat/kanun hazırlama, hayvan să̆gl̆ğı, halk sağll̆̆g, hasta bakımı, laboratuvar tanısı, aşı ve ilaç tedariki, iletişsim ve afet yönetimi gibi konularla ilgilerinden dolayı konuya müdahil olmaları olarak tanımlanmaktadır. Halkın katılımı ise, kişilerin pandemi ile ilgili sorumlulukların bilmelerini ve fikir beyan etmelerini sağlayarak ihtiyaç duyulacak yerel bilgi ile kaynakların en verimli şekilde kullanılması ve koruyucu önlemlere uyumların azami seviyeye çılkaracak etkili bir yöntemdir".}

Hastalık ortaya çıkmadan daha da önemlisi salgın kararı alınmadan önce hazırlanmış olan plan, kriz yönetimi sürecinde izlenecek yol ve yöntemlerin, alınacak olan kararların, uygulanacak politikaların, oluşturulacak yönetsel yapıların neler olacağı hakkında önemli bir rehber olmuştur. Bu aşamada sürecin yönetiminde birtakım ilkelerin esas alınması gerekmektedir. Nitekim Aven ve Renn (2018:231)'in belirlediği risk yönetimi sürecinde hükümetlerin uygulaması gereken ilkeler Tablo 5 'te gösterilmektedir.

Tablo 5. Risk Yönetimi Süreci İlkeleri

\begin{tabular}{|c|l|}
\hline Açıklık ve şeffaflık & $\begin{array}{l}\text { Hükümetin halka yönelik risklerin doğası ve anlayışı hakkında ve bunları ele } \\
\text { alırken izlediği süreç hakkında açık ve şeffaf olması }\end{array}$ \\
\hline Katılım & Hükümet, karar alma sürecinden etkilenenlerin geniş katılımını sağlaması \\
\hline Orantılılık ve tutarlılık & Hükümetin riskle mücadele sürecinde orantılı hareket etmesi \\
\hline Kanıt & Hükümet kararları ilgili tüm konuları kanıtlara dayandırması \\
\hline Sorumluluk & Hükümetin, riskleri kontrol etmek için risk yönetimi sorumluluğunu üstlenmesi \\
\hline
\end{tabular}

Kaynak: Aven ve Renn, 2018:231. 
Türkiye'nin salgınla mücadele sürecinde bu ilkeleri gözeten bir politika uyguladığı gözlenmektedir. Kamuoyunun bilgilendirilmesi, karar alma süreçlerine Bilim Kurulu tavsiye kararları üzerinden katılım sağlanması, alınan tedbirler konusunda ölçülü davranılmasına özen gösterilmesi ve istisnai koşulların belirlenmesi, kanıta ve veriye dayalı açıklamalar yapılması ve ilgili kurum ve kuruluşların görev alanlarıyla ilgili olarak sorumluluk üstlenmesi bunlar arasında sayılabilir. ${ }^{7}$ Ayrıca bu süreçte hazırlık planı ve sağllk altyapısı ile sağlık altyapısını destekleyen diğer altyapı olanaklarının risk yönetimi sürecinin hazırlıklı olma ve risk azaltma aşamalarına denk geldiği belirtilebilir. Şekil 5'te kamu politikası, risk yönetimi ve kriz yönetimi ilişkisel gösterimi yer almaktadır.

Şekil 5. Kamu Politikası, Risk Yönetimi ve Kriz Yönetimi İlişkisel Gösterimi

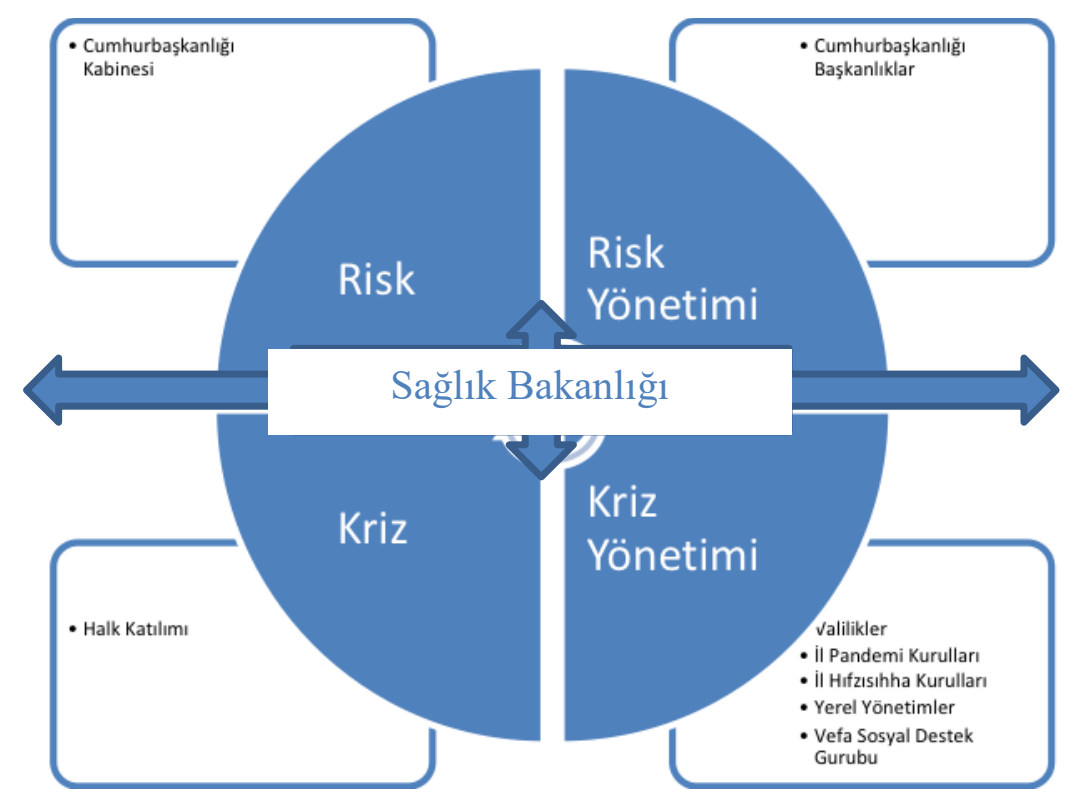

\section{SALGINDA KRİZ YÖNETIMM SÜRECI OLARAK TEDBİR STRATEJİİ}

Salgının bir kamu politikasına dönüşme sürecinin kamu politikası analizi çerçevesinde ele alınması yerinde olacaktır. Kamu politikası analizinde gerek ulusal gerekse de uluslararası düzeyde çok önemli çalışmalar yapılmaktadır. Genel olarak kamu politikası analizinde çeşitli kuramsal yaklaşımlara değinilmiş ve seçilen kuramsal yaklaşım çerçevesinde belirlenmiş alanlara ilişkin kamu politikası analizleri yapılmıştır. Örneğin, Yıldız ve Sobacı (2013) tarafından derlenen Kamu Politikası: Kuram ve Uygulama isimli çalışmada hem kamu politikası ve kamu politikası analizine yönelik genel bir çerçeve çizilmiş hem de eğitim, sağlık, sosyal politika, göç, çevre, afet yönetimi, kentsel dönüşüm, toplu ulaşım, kamu personel politikası, yerelleşme, yolsuzluk ve edevlet politikaları gibi örnekler üzerinden analizler içeren konular ele alınmıştır. Yine Babaoğlu ve Akman (2018) tarafından derlenen Kamu Politikası Analizi: Türkiye Uygulamaları isimli çalışmada da 25 ayrı başlıkta Türkiye'deki uygulamalar değerlendirilmiştir.

Kamu politikası analizi bakımından bu iki çalışmanın dışında alanın uzmanları tarafından yapılan çok sayıda çalışmanın bulunduğunu da not etmek gerekir. Ancak risk ve kriz yönetimi süreçlerinin kamu politikası analizinde salgınla mücadele örneği üzerinden yeterince ele alınmadığı, konunun afet yönetimi bağlamında analiz edildiğini belirtmek gerekir. Bu bakımdan risk ve kriz yönetimi süreçlerini kamu politikası analizine derç etmek bu çalışmada üzerinde durulan konulardan biri olmuştur. Kamu politikası analizi için geliştirilmiş olan yaklaşımlar genel hatlarıyla şunlardır: süreç yönetimi yaklaşımı, ağ yönetimi yaklaşımı, referans modeli ve bilişsel yaklaşım (Usta, 2013), rasyonel aktör modeli, arttırımcı model, karma modeller, grup modeli, elitist model, kurumsal model, kamu tercihi modeli, sistem yaklaşımı ve süreç yaklaşımı (Babaoğlu, 2017). Genel olarak kamu politikası aktörler, tasvirler, kurumlar, süreçler ve sonuçlar gibi unsurları içermektedir (Usta, 2013:82). Şekil 6'da kamu politikaları unsurları gösterilmektedir.

7 Sorumluluk üstlenmeyle ilgili olarak İçişleri Bakanı'nın sokağa çıkma kısıtlamasının ilan edilmesi sürecinde yaşanan olumsuzlukları üstlenip istifa etmesini örnek olarak gösterebiliriz. 
Şekil 6. Kamu Politikalarının Unsurları

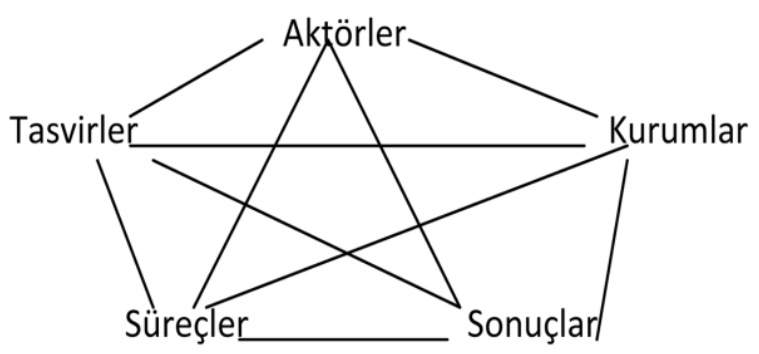

Kaynak: Usta, 2013.

$\mathrm{Bu}$ yazıda aktörler ve kurumlar aynı başlık altında değerlendirilmiş, süreçler ise uygulanan politikalar olarak betimlenmiş, risk yönetimi ve kriz yönetimi bu başlık altında ele alınmıştır. Burada tercih edilen yöntem aktör/politika diyalektik ilişkisi olmuştur. Bundan ötürü olağan bir kamu politikası analizinden farklı olarak salgın sürecinin meydana gelmesinde rol oynamaktan çok salgının gündeme gelmesiyle birlikte aktörlerin ve kurumların sürece müdahalesi şeklinde bir olgunun meydana gelmesidir söz konusu olan. Daha önce ifade edildiği üzere kamu politikası yaklaşımlarından biri olan süreç yaklaşımına göre (Usta, 2013:86);

“...öncelikle problem tanımlanmakta ve gündeme alınmakta, arkasından çözüm önerileri ortaya konulmakta ve bu çerçevede hukuki alt yapr oluşturulmaktadır. Daha sonra ise program uygulamaya konulmakta ve bu aşamada ölçütler belirlenmekte, veriler ölçülmektedir. Son aşamada ise problemin çözümü ile birlikte program sonlandırılmaktadır".

Türkiye'nin salgınla mücadele politikası bu yaklaşım çerçevesinde ele alındığında, önce salgın probleminin tanımlanıp gündeme alındığı, çözüm stratejileri için öneriler geliştirildiği, katılım mekanizmalarının çalıştırıldığı, kararların Bilim Kurulu tavsiyeleri doğrultusunda kanıta dayalı olarak alındığı ve bu aşamada tedbir stratejisinin belirlenerek ona uygun hukuki altyapı oluşturulduğu ve yasal düzenlemeler ile desteklendiği, benimsenen stratejinin uygulamaya konduğu ve gelişmelerin anlık olarak değerlendirilip izlendiği görülmektedir.

Salgın probleminin kendisi bir kriz durumu olarak tanımlandığı için izlenen yol ve yöntemlerin ve karar alma süreçlerinin de kriz yönetimi süreçleri doğrultusunda yürütüldüğü söylenebilir. Hastalık ortaya çıtıktan sonra Dünya Sağlık Örgütü (DSÖ) henüz “pandemi” kararı almadan önce yurtdışındaki temaslarında Cumhurbaşkanı, görüştügü liderlerle tokalaşmayarak ve sosyal mesafeyi koruyarak bir anlamda salgına dikkat çekmiştir. Türkiye'de ilk Koronavirüs vakasının 11 Mart 2020 tarihinde tespit edilmesiyle birlikte izlenecek kamu politikasının ana hatları da belirginleşmeye başlamıştır. "Hiçbir virüs, alınacak tedbirlerden daha güçlü değildir", denilerek izlenecek tedbir politikalarına işaret edilmiştir. Bu bağlamda Türkiye'nin izlediği salgın ile mücadele politikasının "tedbir politikası" olduğu belirtilebilir. Türkiye aynı zamanda afet yönetimi bakımından önemli unsurlardan biri olan sorunu tespit ederek salgının küresel olmakla birlikte mücadelenin ulusal düzeyde gerçekleştirileceğini belirtmiştir. Böylece diğer afet türlerinden farklı olarak etkileri küresel düzeye yayılan salgın afetiyle mücadele etmek için önce sorun tespit edilmiş ardından sorunu çözmek üzere "tedbir stratejisi" benimsenerek uygulanmaya başlanmıştır. Bu stratejinin aşağıda belirtilen dört ana hedef etrafinda yürütüldügü ifade edilmiştir (www.tccb.gov.tr, 2020):

- Fiziki mesafenin temini

- Sağlık sisteminin ayakta kalması

- Temel ihtiyaç maddeleriyle ilgili üretim ve tedarik zincirlerinin aksamaması

- Kamu düzeninin devam etmesi

Kısmi sınırlamalar da içeren bu stratejinin dişında dünyada başlangıçta İngiltere tarafından uygulanan, ancak vazgeçilen "serbest bırakma/sürü bağış̧ıllğglmüdahalesizlik)" stratejisi (O'Grady, 2020) ile Çin'in uyguladığg "baskicl/sert" stratejisinin de var olduğunu belirtmek gerekir (Kupferschmidt ve Cohen, 2020:1062). Öte yandan Duran (2020) tarafından yapılan bir çalışmada dünyada pandemiyle mücadele sürecinde bastırma (suppression) ve yatıştırma (mitigation) stratejilerinin benimsendiğini ve Türkiye'nin izlediği stratejinin sert 
müdahaleleri de içerebilen bastırma stratejisi olduğunu ifade etmektedir ${ }^{8}$. Ancak bu çalışmada tedbir stratejisi kavramının kullanılması tercih edilmiştir. Dolayısıyla tedbir stratejisini esas alarak KOVID-19 ile mücadele politikasını sürdüren Türkiye'nin 4 Mayıs 2020 tarihine dek bu stratejiye sadık kalarak politika üretmiş olduğu söylenebilir.

\subsection{Tedbir Stratejisinin Aktörleri}

Gerek kamu politikası analizinde gerekse afet yönetimi sürecinde karar vermekle ve süreci yönetmekle yükümlü aktörler bulunmaktadır. Türkiye açısından konu değerlendirildiğinde Cumhurbaşkanlığı Hükümet Sistemi’nin bir sonucu olarak ana aktörün Cumhurbaşkanlığ 1 olduğu görülmektedir ${ }^{9}$. Hem bir kamu politikası olarak gündeme alınması hem sorunun ortaya konması hem de mücadele stratejisinin benimsenmesinde bu yapının etkin olduğu, ancak karar alma sürecini doğrudan etkileyen diğer güçlü aktörlerin de bulunduğunu ifade etmek gerekir $^{10}$. Bu açıdan değerlendirildiğinde ve sorunun küresel olması bununla birlikte mücadelenin ulusal bir çerçevede sürdürülmesi süreç yönetiminin çok aktörlü bir nitelik taşıdığını göstermektedir. Sağlık, ekonomi, eğitim, teknoloji, toplumsal yapı, güvenlik, denetim başta olmak üzere birçok boyutu barındıran bu sürecin ana aktörleri, Cumhurbaşkanlığı'nın yanı sıra, Sağlı Bakanlığı, İçişleri Bakanlığı, Milli Eğitim Bakanlığı, Tarım ve Hayvancılık Bakanlığı, Sanayi ve Teknoloji Bakanlığı, Ulaştırma ve Altyapı Bakanlığı, Aile, Çalışma ve Sosyal Hizmetler Bakanlığı, Maliye ve Hazine Bakanlığı, Kültür ve Turizm Bakanlığı, Ticaret Bakanlığı, Dış İşleri Bakanlığı, Çevre ve Şehircilik Bakanlığı, Valilikler, Yerel Yönetimler, Uzmanlar ve Bilim İnsanları ile Sivil Toplum Örgütleridir. Ancak KOVID-19 salgını ile birlikte en fazla öne çıkan aktörlerden birinin Sağlik Bakanlığı bünyesinde kurulan Bilim Kurulu olduğu görülmektedir. Bundan dolayı Bilim Kurulu, bu çalışmada daha ayrıntılı ele alınacaktır.

Türkiye'de ilk vaka görülmesinden çok önce, 10 Ocak 2019 tarihinde Sağlık Bakanlığı bünyesinde kurulan Bilim Kurulu'nun üye sayısı, kuruluş aşamasında 26 iken daha sonra 31 kişiye çıkarılmıştır. Türkiye'de uygulanan virüsle mücadele politikalarının ana aktörü olarak işlev gören Bilim Kurulu, yayınlamış olduğu “2019-nCoV Hastalığı Rehberi” ile mücadele sürecini başlatmıştır. Türkiye'nin önde gelen üniversitelerinden alanında yetkin enfeksiyon, mikrobiyoloji, viroloji, iç hastalıkları, pediatri, yoğun bakım ve gögüs hastalıkları uzmanı akademisyenlerin bulunduğu Bilim Kurulu salgın kararı öncesinde ve sonrasında Vuhan'daki Türk vatandaşlarının getirilmesi, uçuşların yasaklanması, kara sınırlarının kapatılması, referans hastanelerinin belirlenmesi, yurt dışı ziyaretlerin ertelenmesi, yurt dışından gelenler için 14 günlük karantina uygulaması, eğitime ara verilmesi, konaklama tesisleri, restoranlar, yurtlar ve huzurevlerinde tedbirlerin artırılması, açık ve kapalı cezaevlerinde açık görüşlerin ertelenmesi gibi önemli tavsiye kararlarında bulunmuştur (Yener, 2020).

Bilim Kurulunun dışında yine salgınla mücadele sırasında virüsün toplum ve ruh sağlığındaki tahribatını en aza indirmek için oluşturulan ve psikologlar, sosyologlar, ekonomistler ve din psikologları ile sosyologlarından oluşan Toplum Bilimleri Bilim Kurulu oluşturulması kararlaştırılmıştır. Bununla birlikte Cumhurbaşkanlığ 1 politika kurullarında da düzenlemeye gidilmiştir. Sağlık ve Gıda Politikaları Kurulu'nun ikiye ayrılarak Gıda, Tarım, Orman ve Hayvancılık Kurulu ile Sağlı ve Sosyal Politikalar Kurulu olarak düzenlenmesi kararlaştırılmıştır.

Bilim Kurulu'nun kurulmasına dayanak teşkil eden ve 2019'da Sağlık Bakanlığı Halk Sağlığı Genel Müdürlüğü tarafından hazırlanan Pandemik İnfluenza Ulusal Hazırlık Planı'na da değinmekte yarar olacaktır. Öncelikle belirtmek gerekir ki pandemi yönetiminin planlamasında ve pandemi durumunda sorumluluk Sağlik Bakanlı̆̆g'na verilmiştir. $\mathrm{Bu}$ anlamda özellikle yürütülen sürecin büyük oranda Sağlı Bakanlığı sorumluluğunda gerçekleştirildiği göz ardı edilmemelidir. Bahsi geçen plana göre pandemi sırasında

8 Duran (2020), bastırma stratejisini, merkezden çevreye ya da üst basamaklardan alt basamaklara doğru hiyerarşik bir örgütlenme gerektiren virüse karşı daha merkezi ve daha etkin bir mücadeleyi öngörürken mücadele için her türlü kısıtlayıcı önlemin alınmasına imkan sağlayan strateji, yatıştırma stratejisini ise devletlerin salgının etkisini kısa vadede durdurmak yerine uzun vadede yavaşlatması ve bu şekilde sağlık hizmetlerine yönelik ihtiyacın zirveye çıktığ dönemde virüse karşı en riskli grupta bulunanların korunması stratejisi olarak tanımlanmaktadır.

9 Sağlık Bakanı'nın, “Cumhurbaşkanlığı Hükümet Sistemi’nin bu süreçte özellikle kararların hızlı alınmasında oluşturduğu sonuç ve başarının bu olduğuna inanıyorum" şeklindeki açıklaması Cumhurbaşkanlığı Hükümet Sistemi'ne vurgu yapmaktadır (Sağlık Bakanlığı, www.saglik.gov.tr Erişim Tarihi: 09.03.2020).

$10 \mathrm{Bu}$ süreç Cumhurbaşkanlığ 1 Hükümet Sistemi’nin kriz yönetimi sürecinde ve merkezi yönetim yerel yönetim ilişkilerinin uygulamaya nasıl yansıdığını göstermesi bakımından izlenmesi gereken bir süreç olma özelliği taşımaktadır. 
TURAN, Abdulmenaf ve ÇELIKKYAY, Hicran HAMZA - Türkiye'de KOVID-19 ile Mücadele: Politikalar ve Aktörler

Bakanlıklar/Kurumlar arası koordinasyonu sağlamak amacı ile Sağlık Bakanlığı bünyesinde, Ulusal Koordinasyon Kurulu oluşturulması önerilmektedir.

Ulusal Pandemi Danışma Kurulu ve Ulusal Koordinasyon Kurulu sekretaryasını yürütmek üzere kurulan Bakanlık Operasyon Merkezi'nin başkanlığını Halk Sağlığı Genel Müdürü veya yetkilendireceği kişi yürütmekte ve birim sorumluları görevlendirilmektedir. Konuyla ilgili uzmanlardan oluşan Ulusal Pandemi Danışma Kurulu, Bakanlık Operasyon Merkezi bünyesinde yer alan bir kuruldur ve görevleri şöyle tarif edilmiştir;

- Pandemiye yönelik bilimsel danışmanlık (vaka yönetim algoritmasının oluşturulması, güncellenmesi),

- Pandemi ile ilgili araştırmaların planlanması (elde edilen verilerin analiz edilerek teknik destek verilmesi vb. sağlanması),

- Medya ve iletişim konusunda destek sağlanması,

- Danışma kurulu üyelerinden seçilen sözcüler tarafından risk iletişimi birimi ile ortaklaşa halka yönelik bilgilendirme yapılmasının sağlanması.

Öte yandan planda Sağlı Bakanlı̆̆ı tarafından, 2009 pandemisi ile ilgili deneyimler ve çıkarılan dersler konusunda Bilimsel Danışma Kurulu'na şu şekilde atıf yapılmıştır; “... pandemi planında tanımlanmış ve pandemi sırasında iyi işlev görmüş olan Bilimsel Danışma Kurulu'nun işleyiş̧ ve kamuoyuna yönelik iletişim çalışmalarındaki rolünün planda daha açık tarif edilmesi (kurul sözcüsü, görevleri vb.) gerektiği...". Son olarak planda yine 2009 pandemisi ile ilgili deneyimler ve çıarılan dersler konusuna yer verilirken Bilim Kurulu ifadesi geçmektedir;

- Pandemi Bilim Kurulu tarafından o dönemdeki gelişmeler dikkate alınarak bir algoritma geliştirilmiş ve uygulanmıştır.

- Hastalığın özelliklerine göre pandemi sırasında ortaya çıkabilecek yeni risk grupları da bu listelere hızla dâhil edilebilmelidir. Pandemi Bilim Kurulunun yaptı̆̆ bu ve benzeri güncellemeleri içeren bilimsel öneriler, sürecin gelişimine katkı sağlamak açısından önemlidir.

Bu bilgilerden anlaşıldığı üzere, Bilimsel Danışma Kurulu ile Pandemi Bilim Kurulu aynı kurulları ifade etmekte iken Ulusal Pandemi Danışma Kurulu ise Bakanlık Operasyon Merkezi bünyesinde kurulan bir kuruldur. Yine 10 Ocak 2020 tarihinde kurulan Bilim Kurulu'nun ise daha önceki influenza, H1N1, kuş gribi gibi hastalıklar için de kurulan bir bilim kurulu olduğu anlaşılmaktadır (Yalçınkaya, 2020). Yine dikkate değer konulardan biri de Pandemik Influenza Ulusal Hazırlık Planı'nında yer alan İl Pandemi Kurullarının ve Umumi Hıfzısıhha Kurullarının çalışmaya başlamasıdır. Buna göre, il pandemi kurullarının illerin özel durumlarını gözönünde bulundurarak yerel düzeyde tedbir almak üzere tavsiye niteliğinde görüşler sunarak ve merkezi düzeyde alınan kararların uygulama sürecine katkı sunacak şekilde tasarlanmıştır. Bu süreçte öne çıkan aktörlerden biri de il/ilçe emniyet müdürü, il/ilçe jandarma komutanı, vali/kaymakamlar tarafindan belirlenecek kamu kurum ve kuruluşlarının temsilcileri, yerel yönetimler, AFAD, Kızılay ve ihtiyaç duyulacak sivil toplum kuruluşları temsilcilerinden oluşturulan Vefa Sosyal Destek Gurupları olmuştur.

\subsection{Salgın Sürecinde İzlenen Politikalar}

Çalışmanın bu bölümünde salgın sürecinde izlenen politikalar belirli başlıklar altında ele alınmıştır. Bu süreçte uygulamaya koyulan politikaların dört temel alan etrafında yoğunlaştığı görülmektedir. Bu alanlar; Toplumsal Bilinçlendirme Çalışmaları, Ulaşım ve Dolaşımın Kısıtlanması, Ekonomik Önlemler ve Düzenlemeler, Sosyal Yardım ve Toplumsal Dayanışmanın Güçlendirilmesi şeklinde düzenlenmiştir.

Gündemi fazlaca meşgul eden ve vatandaş katılımının yoğun olarak desteklendiği evde kal çağrısı, sosyal, kültürel ve sportif faaliyetlerin kısıtlanması, ülke içi dolaşımının düzenlenmesi, uzaktan eğitim modeline geçilmesi gibi birçok uygulama ele alınırken diğer yandan da düzensiz göçmenler ve mültecilerin durumu, vergi ve kredi erteleme muafiyetleri, Türkiye-İran sınırına getirilen kısıtlamalar gibi süreci tamamlayan ve bütünsel yürütülmesini sağlayan politikalara da yer verilmiştir. Ayrıca, Umre'den gelen vatandaşların durumu, kısmi sokağa çıkma kısıtlamaları, maske temini gibi yer yer kamuoyunda tartışmalara neden olan uygulamalar da bölüm içerisinde ele alınmaktadır. 


\subsubsection{Toplumsal Bilinçlendirme Çalışmaları}

Hem risk hem de kriz yönetimi sürecinde en temel unsurlardan biri bilgilendirme ve bilinçlendirme çalışmalarıdır. Bu açıdan değerlendirildiğinde salgın ortaya çıktığı andan itibaren halkın salgın konusunda bilgilendirilmesine ve bilinçlendirilmesine yönelik çalışmalara başlandığı belirtilebilir. Bu çalışmalar kapsamında ilk olarak Bilim Kurulu'nun önerisiyle 14 Ocak 2020'de hazırlanmış olan ve 14 Nisan 2020'de güncellenen Sağlık Bakanlığı tarafından hazırlanmış olan "COVID-19 (SARS-CoV-2 Enfeksiyonu) Rehberi”dir. Bu rehber ilk yayınlandığı andan itibaren el ilanı, afiş, video, kitapçık şeklinde yazılı, görsel ve sosyal medya araçları üzerinden toplumun her kesimine ulaştırılarak hastalık belirtileri, hastalıktan korunma yolları gibi konular hakkında toplumsal bilinçlendirme çalışmaları yapılmıştır. ALO 184 SABİM Korona Danışma Hattı kurulması da bu kapsamda değerlendirilebilir. Bu politikaların en önemli aktörleri Sağlı Bakanlığı, Cumhurbaşkanlığ İletişim Başkanlığı, belediyeler ve sivil toplum örgütleri olmuştur.

\subsubsection{Evde Kal Uygulamaları ve Dini, Sosyal, Kültürel ve Sportif Faaliyetlerin Kısıtlanması}

Tedbir stratejisinde virüsün yayılmasını engellemek için uygulanan yöntemlerden biri evde kal uygulaması olmuştur. Başlangıçta gönüllülük esasıyla uygulanan bu yöntem daha sonraki süreçte 30 büyükşehir ve Zonguldak ili için belirli aralıklarla uygulanan zorunlu sokağa çıkma kısıtlamasına dönüşmüştür. Evde kal uygulamasını desteklemek üzere spor müsabakalarının Nisan sonuna kadar seyircisiz oynanması, hemen ardından tüm ligler ve müsabakaların ertelenmesi, hastanelere ziyaretçi kısıtlaması getirilmesi, Mart ve Nisan aylarında düzenlenecek ulusal ve uluslararası bilimsel açık ya da kapalı toplantı, kongre, konferans gibi etkinliklerin geçici bir süreyle ertelenmesi, açık ve kapalı cezaevlerindeki görüşlerin ertelenmesi, duruşma ve diğer adli işlemlerden ivedi özelliği bulunmayanların ertelenebilmesi, yurt içi fuarların ertelenmesi gibi önlemler alınmıştır.

İçişleri Bakanlığı tarafından yayınlanan 26 Mart 2020 tarihli genelge ile büyükşehir, il, ilçe, belde belediyeleri ve mahalli idare birlikleri meclisleri ile il genel meclislerinin Nisan, Mayıs ve Haziran ayı toplantılarının ertelenmesi, ancak zorunlu hallerde sağlık tedbirlerinin alınması koşuluyla olağanüstü toplantı yapılabileceği belirtilmiştir (www.icisleri.gov.tr Erişim Tarihi: 26.03.2020).

İçişleri Bakanlığı tarafından yayımlanan Koronavirüs Salgını ile Mücadele Kapsamında Park, Mesire, Piknik Yerleri İle İlgili Ek Genelge ile 28-29 Mart 2020 tarihleri başta olmak üzere virüsle mücadele sağlanıncaya kadar hafta sonlarında, il ve ilçelerde vatandaşların sahil bantları, mesire ve ören yerlerinde, piknik alanlarında; piknik yapmak, balık tutmak, spor, yürüyüş vb. faaliyette bulunmak yasaklanacağ 1 , il ve ilçelerin durumuna göre bu tedbirlerin hafta içi günlerine de yaygınlaştırılabileceği belirtilmiştir. Yine bu kapsamda 16 Mart 2020 tarihi itibariyle Cuma namazı başta olmak üzere cami ve mescitlerde cemaatle namaza ara verilmiş ve bu tedbirlerin Ramazan ayında teravih namazları için de geçerli olduğu kararlaştırılmıştır. Öte yandan toplumsal düzenin sağlanması için denetim ve güvenlik tedbirleri kapsamında, maske, eldiven ve tulum gibi sıhhi malzemelerde piyasalardaki aşırı fiyat artışıyla mücadele edilmesi bu alandaki ilk uygulama olarak karşımıza çıkmaktadır. Daha sonraki süreçte bu denetimlerin gıda alanına doğru genişletilmesi söz konusu olmuştur.

\subsubsection{Ulaşım ve Dolaşımın Kısıtlanması}

KOVID-19 ile mücadele politikasının en önemli unsurlarından biri sosyal hareketliliği önlemek için aşamalı olarak gerçekleştirilmiş olan seyahat sınırlamaları olmuştur. Sağlık Bakanlığı internet sayfasından derlenen bilgilere göre 1 Şubat 2020 tarihinde Çin'in Vuhan kentinden tahliye edilen 42 kişinin 14 günlük karantinaya alınması ile başlayan süreç şehirlerarası seyahat sınırlamasına kadar aşamalı olarak devam etmiştir. Vaka sayısının Uzak Doğu Asya'da artmasıyla birlikte Japonya, Tayvan, Tayland, Singapur, Güney Kore ve Malezya'dan gelen uçuşlara termal kamera uygulaması getirilmiş ve Çin'den gelen bütün uçuşlar 3 Şubat 2020 tarihi itibariyle durdurulmuştur.

23 Şubat'ta İran'a yapılan uçuşların yasaklanmasının ardından 29 Şubat'ta Irak, İtalya ve Güney Kore'ye yapılan uçuşlar yasaklanmış, Azerbaycan, Gürcistan, Almanya, Fransa, İspanya, Norveç, Danimarka, Belçika, Avusturya, İsveç ve Hollanda'ya uçuşlar ise 14 Mart 2020 tarihi itibariyle yasaklanmıştır. 16 Mart 2020 tarihi itibariyle de İngiltere, İsviçre, Suudi Arabistan, Mısır, İrlanda ve Birleşik Arap Emirlikleri ile uçuşları yasaklanarak uçuş yasağı uygulanan ülke sayısı 20'ye ulaşmıştır. 21 Mart 2020 tarihi itibariyle 46 ülkeye daha uçuş yasağı uygulanmıştır.

17 Mart 2020 tarihinde 9 farklı Avrupa ülkesinden 2.807 Türk vatandaşının tahliyesi ile yurtdışında eğitim gören öğrencilerin tahliyesi gerçekleştirilmiştir. 15 Nisan 2020 tarihi itibariyle yurt dışında bulunan 70 ülkeden 
25 bin 4 Mayıs 2020 itibariyle toplamda 65 bine yakın vatandaş Türkiye'ye getirilmiştir (www.tccb.gov.tr, 2020). Tahliye süreci talepler doğrultusunda sürdürülmektedir. Dışişleri Bakanlığı, Ulaştırma ve Altyapı Bakanlığı bu sürecin ana aktörleri olmuşlardır.

\subsubsection{Türkiye-İran Sınırına İlişkin Kısıtlama}

Türkiye ile kara sınır komşusu olan İran'ın Kum kentinde ortaya çıkan vakalardan dolayı Ağrı Gürbulak, Van Kapıköy, Hakkâri Esendere ve Iğdır'dan özerk Nahçıvan bölgesine açılan Dilucu Sınır Kapısı'nda termal kamera sistemine geçilmiş, 23 Şubat 2020 tarihi itibariyle adı geçen sınır kapılarının geçici olarak kapatılması kararı alınmış, kara ve demiryolu geçişleri ile tüm uluslararası uçuşlar ise tek taraflı ve geçici olarak geçici olarak durdurulmuş ancak Türkiye'den İran'a gidişler ise devam ettirilmiştir. Bu süreçte İran ile kara sınırında sahra hastaneleri kurulmuş, İran uyrukluların ülkeye alınmayacağı ancak gelmek isteyen Türk vatandaşlarına 14 günlük karantina sürecine göre işlem yapılacağı bildirilmiştir.

\subsubsection{Umre'den Gelen Vatandaşlar}

Bu süreçte en çok tartış1lan konulardan biri Umre'den gelen vatandaşlara yönelik uygulamalardır. Diyanet İşleri Başkanlığı tarafindan 15 Mart 2020 tarihinde yayımlanan basın bildirisine göre 27 Şubat 2020 tarihinden itibaren umre çıkışlarının durdurulduğu, hâlihazırda giden vatandaşlar için ise erken dönüş planlaması yapıldığı belirtilmektedir. Yurda dönen vatandaşlar için başlangıçta 14 gün boyunca karantina uygulamaları, dışarı çıkmamaları önerilmiştir. İlk dönem dönen vatandaşlara havalimanında sağlık kontrolleri yapılmış, zorunlu karantina uygulanmamıştır. Ne yazık ki ilk dönemde sadece "öneri” şeklinde yapılan uyarı, bir kısım vatandaşlar nezdinde yeterince karşılık bulamamıştır. Tedbirin vatandaşların inisiyatiflerine bırakılması bu bağlamda eleştirilere neden olmuştur.

İkinci dönemde Umre'den dönen vatandaşlar için Sağlık Bakanlığı tarafından farklı tedbir önlemleri uygulanmış, vatandaşlara Ankara ve Konya'daki Kredi ve Yurtlar Kurumuna ait öğrenci yurtlarında zorunlu karantina uygulaması başlatılmıştır (www.diyanet.gov.tr, 2020). Başlangıçta 14 günlük evde izolasyon tedbirinin benimsendiğini ancak daha sonra gelen tüm vatandaşların Ankara ve Konya'da öğrenci yurtlarında 14 günlük karantinaya alınarak tedbirin sıkılaştırıldığını görülmektedir.

\subsubsection{Düzensiz Göçmenler ve Geçici Koruma Statüsündeki Mülteciler}

KOVID-19 Salgını öncesinde Türkiye'nin en önemli gündem maddelerinden biri, 33 askerin İdlib'de şehit düşmesinin ardından Avrupa'ya gitmek isteyen mülteciler için 28 Şubat 2020 tarihi itibariyle Türkiye'nin tüm sınır kapılarını açması ve Türkiye-Yunanistan sınırında toplanan yaklaşık 13 bin göçmenin içinde bulunduğu durum olmuştu.

Salgının başlaması ile göçmenlerin 21 Mart 2020 tarihi itibariyle kontrollü şekilde sınır bölgelerinden nakilleri yapılmaya başlanmıştır. Sağlık kontrolünden geçirilen göçmenler, yurdun çeşitli yerlerindeki İl Göç İdaresi Müdürlüğü Geri Gönderme Merkezlerine (CNN Türk, 2020a), bir kısmı ise daha sonra uygun bölgelere gönderilmek üzere misafirhanelerde karantina altında tutulmaya başlanmıştır (www.sabah.com.tr, 2020).

10 Nisan 2020'de Sağlık Bakanı, Türkiye sınırları içinde yaşayan herkesin KOVID-19 ile mücadele kapsamında açıklanan resmi verilere dahil edildiğini belirtmiştir. Halihazırda Türkiye sınırları içerisinde olan tüm mülteciler ve düzensiz göçmenler tüm sağlık hizmetlerinden yararlanmakta ve durumları kayda alınmaktadır. Ayrıca, İl Göç İdaresi Genel Müdürlüğü internet sitesinde KOVID-19 mücadelesi kapsamında çeşitli bilgilendirmeler yapmaktadır. 10 Nisan akşamı ilan edilen "sokağa çıkma yasağı" ile ilgili genelge 7 farklı dilde hazırlanarak yayınlanmıştır (www.goc.gov.tr). Bu sürecin yürütülmesinde İçişleri Bakanlığı ana aktör olarak rol üstlenmiştir.

\subsubsection{4. Ülke İçi Dolaşımın Kısıtlanması}

24 Mart 2020 tarihli İçişleri Bakanlığı genelgesi ile tüm şehir içi ve şehirlerarası çalışan toplu taşıma araçlarının, geçici bir süreliğine araç ruhsatında belirtilen yolcu taşıma kapasitesinin \%50'si oranında yolcu kabul edeceği kararlaştırılmıştır. 81 İl Valiliğine Koronavirüs Tedbirleri Kapsamında Uçak/Otobüs Seferleri Genelgesi ve Koronavirüs Tedbirleri Kapsamında Şehirlerarası Otobüs Yolcu Taşımacıllğı İle İlgili Ek Genelge ile ülke içi dolaşıma sınırlamalar getirilmiştir (www.icisleri.gov.tr, 2020).

İlk genelgeye göre, havayolu ile düzenlenecek uçuşlarda da yolcuların, Seyahat İzin Belgesi olmadan seyahat edemeyeceği, hizmetine ihtiyaç duyulan üst düzey kamu görevlileri ile kamu hizmeti yürütenlerin görevleri çerçevesinde seyahat etmelerinde kısıtlama olmayacağı, tedavi ihtiyaçları nedeniyle doktor kararıyla sevk edilen, birinci derece yakınları vefat eden veya ağır hastalığı olanlar, özellikle son on beş gün içerisinde gelmiş 
olduğu yerde, kalacak yeri bulunmayan vatandaşların, Seyahat İzin Kurullarından seyahat izin belgesi alarak hava yolu ile seyahat edebileceği kararlaştırılmıştır.

Ek genelge ile de iller arası otobüs seferlerinin 28.03.2020 tarihinden itibaren ancak valiliklerin izni ile yapılabileceği, Seyahat İzin Kurulu kurularak talebi uygun görülenlere kurul tarafindan seyahat güzergâhı ve süresini de içerecek şekilde şehirlerarası otobüs seyahat izin belgesi düzenleneceği ve gerekli hijyen ve koruma tedbirlerinin alınacağı kararlaştırılmıştır. Bu düzenlemede tüm vatandaşların bulundukları şehirde kalmaları gerektiği yönündeki tavsiye kararına yeterince uygun davranılmaması, peşinden daha sıkı tedbirlerin getirilmesine yol açmıştır. Nitekim 3 Nisan 2020 tarihli İçişleri Bakanlığı Genelgesi uyarınca büyükşehir statüsündeki 30 il ile Zonguldak il sınırlarından kara, hava ve deniz yolu ile (toplu ulaşım aracı, özel araç ve yaya vb.) yapılacak tüm giriş/çıkışlar 15 günlük bir süre için geçici olarak ve istisnai kimi durumları içerecek şekilde durdurulmuştur ${ }^{11}$. Yine 30 Mart 2020 tarihi itibariyle İstanbul, Ankara ve İzmir illerinde kayitlı ticari taksilerin trafiğe çıkışlarında plakasının son hanesine göre sınırlamaya gidilerek sosyal izolasyon sağlanmaya çalışılmıştır. Ayrıca 4 Nisan 2020 itibariyle Türk Hava Yolları'nın iç hat seferleri 20 Nisan'a kadar durdurulmuştur.

\subsubsection{Kısmi Sokağa Çıkma Kısıtlamaları}

21 Mart 2020 tarihli Genelgeyle ve daha sonra 4 Nisan 2020 tarihli Cumhurbaşkanlığı Kararıyla kapsamı genişletilecek kısmi sokağa çıkma kısıtlamaları süreci başlatılmıştır. Bu konudaki ilk genelge ile 65 yaş ve üzeri ile bağışıklık sistemi düşük ve kronik akciğer hastalığı, astım, KOAH, kalp/damar hastalığı, böbrek, hipertansiyon ve karaciğer hastalığı olanlar ile bağışıklık sistemini bozan ilaçları kullanan vatandaşların 21 Mart saat 24.00 'den sonra ikametlerinden dışarı çıkmaları, açık alanlarda, parklarda dolaşmaları ve toplu ulaşım araçları ile seyahat etmeleri sınırlandırılarak sokağa çıkmalarını kısıtlanmıştır.

3 Nisan 2020 tarihi itibariyle sokağa çıkma kısıtlamasının kapsamı genişletilmiştir. İçişleri Bakanlığı Genelgesi uyarınca tüm il ve ilçelerde 01.01.2000 tarihinden sonra doğmuş olanların sokağa çıkmaları geçici olarak kısıtlanmıştır. Aynı genelgede pazar yeri, market ve toplu olarak çalışılan işyerlerine vatandaşların ve çalışanların maske ile girmeleri, maske takma zorunluluğunun pazarlarda satıcılar için de geçerli olacağı, meydanlarda sokak ve caddelerde; vatandaşların sosyal mesafeyi gözetmeden toplu olarak yürümelerine veya bulunmalarına izin verilmeyeceği kurallara uymayanlar hakkında cezai işlem yapılacağı belirtilmiştir (www.icisleri.gov.tr, 2020).

10 Nisan 2020'de alınan kapsamlı sokağa çıkma kısıtlaması kararı uyarınca, 10.04.2020 tarihi saat 24:00'den 12.04.2020 tarihi saat 24:00 arasında büyükşehir statüsündeki 30 il ve Zonguldak'ta yaşayan vatandaşların sokağa çıkması kısıtlanmıştır (www.icisleri.gov.tr, 2020). Ancak bu kararın aynı gün ve kısıtlamanın başlamasına yaklaşık 2 saat önce ilan edilmesi, resmi açıklama öncesinde bazı yayın organlarında "son dakika" şeklinde haberin geçilmesi, yasak süresince acil tıbbi ihtiyaçlar için nöbetçi eczanelerin, ekmek ihtiyacı için ise firınların açık olacağı gibi yasağın kapsamı konusunda açıklamanın geç gelmesi paniğe yol açmış, vatandaşların kimi ihtiyaçlarını karşılamak için açık işyerlerinden alışveriş yapmak üzere sokağa çıkmasına, sosyal mesafe ve tedbirlere uyulmamasına neden olmuştur. $\mathrm{Bu}$ durum bu zamana kadar uygulanan başarılı tedbirlerin bir anlamda zayıflamasına neden olmuş, kısıtlamanın ilan edilme şekli kamuoyunda tartışmalara yol açmıştır. Öte yandan aynı nitelikteki sokağa çıkma sınıllaması kararı 17-19 Nisan 2020 ve 22-

$11 \mathrm{Bu}$ istisnalar şunlardır: a-) Temel ihtiyaç (gıda/temizlik vb.) malzemeleri ile ilaç ve tıbbi malzemeler başta olmak üzere tüm ticari faaliyetlerin sürekliliği için gerekli olan ürün ve/veya malzemelerin lojistiği, üretimi ve naklinde yurt içi ve dışı taşımacılık kapsamında görevli olanlar ve araçları; malın cinsi, teslimat yeri/alıcı adresi, teslimat tarihini gösteren taşıma irsaliyesi, teslimat makbuz veya fatura vb. belgeler ile giriş/çıkış yapabileceklerdir. Belirtilen amaçlarla kısıtlanan illere giriş yapanlar, giriş amacını gösteren belgeler ile 72 saat sonrasına kadar teslim ilinden ayrılarak ilk çıkış iline dönebilecektir. $\mathrm{Bu}$ şekilde giriş/çıkışı sınırlandırılan illere giren ticari araç sürücüleri seyahatleri süresince, değişim sürelerine uyarak maske takmak, temas gerektirdiği durumlarda sosyal mesafeye uymak zorundadırlar. b-) Yurt içinde ticari yük/yolcu taşımacılığı yapanlar ile uluslararası yük taşımacılığı yapanların giriş-çıkış yasağ illerimizden transit şekilde geçişlerine müsaade edilecektir. $\mathrm{Bu}$ şekilde transit geçişlerine izin verilen ticari yük taşıyıcıları belirtilen illerde zorunlu dinlenme molaları/süreleri hariç hiçbir şekilde duraklama ya da konaklama yapamayacaklardır. c-) Doğalgaz, elektrik, petrol sektöründe enerji arz güvenliğinin ihtiyaç duyduğu malzemenin nakli ve üretiminin gerçekleşmesinde görevli olanlar ve araçları; enerji sektöründe görevli olduklarına dair ilgili şirket tarafından düzenlenecek olan görev belgesi ve/veya sevk irsaliyesi ile giriş/çıkış yapabileceklerdir. d-) Çalışma hayatı içerisinde yer alan yönetici, çalışan ya da işyeri sahiplerinin ikamet ve işyerlerinin farklı illerde bulunması durumunda iller arasındaki giriş/çıkışları; bu durumu ispatlayan (yerleşim yeri/ikamet belgesi, SGK kayıt belgesi) belgeleri ibraz etmek şartı ile yapılabilecektir. e-) Başta sağlık ve güvenlik olmak üzere kamu görevi ve hizmetinin sürekliliğinin sağlanmasında görevli olanlar; görevli olduklarına dair belge veya kimlikle giriş/çıkış yapabileceklerdir. 
TURAN, Abdulmenaf ve ÇELIKKYAY, Hicran HAMZA - Türkiye'de KOVİD-19 ile Mücadele: Politikalar ve Aktörler

26 Nisan 2020 tarihleri için bu kez 4 günlük olarak alınmıştır. Kararın bu sefer dört gün önce açıklanması ile önceki kısıtlamada yaşanan olumsuz tablolar görülmemiştir. Yine bu süreçte birçok yerleşim birimi karantina altına alınarak salgının yayılması engellenmeye çalışılmıştır.

İçişleri Bakanlığı tarafından yayımlanan genelgeler uyarınca düzenlenen sokağa çıkma sınırlamaları ile belirtilen istisnalara göre, başta ekmek üretimi, sağlık ürünleri satış yerleri, kamu ve özel sağlık kuruluşları ile eczaneler, zorunlu hizmet üreten kamu kurum ve kuruluşları ile buralarda görev yapan yönetici, görevli ve çalışanlar ile TBMM temsilcileri vb. sokağa çıkabileceklerdir.

\subsubsection{Maske Temini}

Süreç başladığından beri vatandaşın ne şekilde maske temin edeceği konusunda çok çeşitli kararlar açıklanmıştır. Öncelikle bunda maskenin kullanımı konusunda ülkelere rehberlik etmesi beklenen Dünya Sağlık Örgütü'nün net açıklamalar yapmayışı ve önerilerini sık sık değiştirmesinin de etkisi bulunduğunu belirtmek gerekir. Dünya Sağlık Örgütü, sürecin başında maskeyi sadece enfekte olmuş hastaların kullanması gerektiğini açıklamış, hatta sağlıklı kişilerin maske kullanımının ellerin sık sık yüze götürülmesini ve maske ile temas sağlanmasını kolaylaştıracağı nedeniyle riskli bulmuş, son olarak da korunma amacıyla maskenin mutlaka kullanılmasını tavsiye etmiştir.

Vatandaşın yoğun talebi sonrası maske denetimleri titizlikle uygulanmaya başlanmıştır. Ticaret Bakanlığı tarafından stokçular, hijyen kurallarına ve sağlık standartlarına uymayan merdiven altı üretimler ve fahiş fiyatlara ilişkin denetimler gerçekleştirmiştir. Vatandaşın mağduriyetinin önlenmesi ve gerekli kararların alınması için maske fiyatlarında görülen fiyat artışlarına ilişkin Reklam Kurulu Toplantısı 10 Mart'tan 3 Mart'a çekilmiştir.

3 Nisan 2020 tarihi itibariyle pazar yeri, market ve toplu olarak çalışılan işyerlerine vatandaşların ve çalışanların maske ile girmeleri zorunluluğu kararı sonrasında Ticaret Bakanı, katıldığı bir televizyon programında maskelerin vatandaşa devlet tarafından market önlerinde veya kolay erişilebilecekleri yerlerde satılacağını duyurmuştur (Pekcan, 03.04.2020). Ancak, devlet tarafından satış hiç gerçekleşmemiş, hemen akabinde Sağlik Bakanlı̆̆ı ile Ulaştırma ve Altyapı Bakanlığı'ın almış olduğu kararla çevrimiçi ortamda ePttAVM.com üzerinden vatandaşlara ücretsiz olarak maske temini sağlanacağı duyurulmuş ve maske satışı yasaklanmıştır.

10 Nisan 2020'de ise maskelerin eczaneler aracılığıyla dağıtılacağı ilan edilmiştir. Bu arada devlet teşvikleriyle meslek liseleri başta olmak üzere çeşitli kurumlarda yoğun olarak maske üretimine başlanmış, hatta Türkiye birçok ülkeye maske yardımında bulunmuştur. Nitekim tüm vatandaşların sistematik bir şekilde edinmesi planlanan maskelerin dağıtımı belirli bir düzene oturamamıştır. Kamuoyunda hala tartışmalar bulunmakla birlikte çalışmanın sonlandığı 4 Mayıs itibariyle maske temini konusunda fiyat denetimi şartıyla maske satışına izin verilmiştir.

\subsubsection{Uzaktan Eğitim Modeline Geçilmesi}

İlk, orta ve liselerin 16 Mart'tan itibaren 1 hafta tatil edilmesi ve 23 Mart 2020'den itibaren uzaktan eğitim yöntemiyle eğitim göreceği açıklanmış, ancak salgının etkisinin artması ile birlikte bu kez 30 Nisan 2020 sonrasında 31 Mayıs 2020 tarihine dek uzatılması karara bağlanmış ve sınavlar ertelenmiştir. Ayrıca 13 Mart 2020 tarihi itibariyle de özel kreş, gündüz bakımevleri ile özel çocuk kulüpleri kapatılmıştır. Üniversitelerin ise 16 Mart 2020 tarihi itibariyle 3 hafta tatil edildiği karara bağlanmış ancak bu uygulama da 2019-2020 bahar yarıyılını kapsayacak şekilde uzatılmış, üniversitelerin uzaktan eğitim yöntemiyle bu süreci yürütmesi sağlanmıştır.

\subsubsection{Ekonomik Önlemler ve Düzenlemeler}

18 Mart 2020'de Ekonomide İstikrar Kalkanı programıyla birlikte daralan piyasalara yönelik önlemler alınırken aynı zamanda hastalığın yayılmasına imkan sağlayan ve teması gerektiren ticari faaliyetlere yönelik tedbirler de alınmaya başlanmıştır. İçişleri Bakanlığı tarafından yayınlanan Koronavirüs Tedbirleri başlıklı genelgeler ile ekonomik denetim tedbirleri uygulamalarına katkı sunulmuştur. Örneğin bu genelgelerin etkisiyle 15-18 Mart 2020 tarihleri arasında ülke genelinde 149.382 iş yeri geçici süreliğine faaliyetlerine ara vermiştir. Bu genelgeler ile gece kulüpleri, bar, pavyon, diskotek, tiyatro, sinema, gösteri merkezi, konser salonu, nişan/düğün salonu, çalgılı/müzikli lokanta/kafe, gazino, birahane, taverna, kahvehane, kıraathane, kafeterya, kır bahçesi, nargile salonu, nargile kafe, internet salonu, internet kafe, her türlü oyun salonları, her türlü kapalı çocuk oyun alanları (AVM ve lokanta içindekiler dahil), çay bahçesi, dernek lokalleri, lunapark, yüzme havuzu, hamam, sauna, kaplıca, masaj salonu, SPA ve spor merkezleri faaliyetleri geçici süreliğine durdurulmuştur. Hemen ardından çıkarılan ek genelgelerle berber, kuaför, güzellik merkezlerinin faaliyetleri ile 21 Mart 2020 tarihinden itibaren 
durdurulmuş, içkili ve/veya içkisiz tüm lokanta ve restoranlar ile pastane ve benzeri işyerlerinin, sadece paket servis, gel-al benzeri şekilde, müşterilerin oturmasına müsaade etmeden hizmet verebilmesine imkan sağlanmıştır.

24 Mart 2020 tarihli bir genelgeyle marketlerin çalışma saati ve marketlerde alışveriş yapan müşteri sayısı düzenlenmiştir. 18 Mart 2020 tarihli Ekonomide İstikrar Kalkanı Paketi ile (bir kısmı çalışmanın diğer başlıkları altında değerlendirilen) bir dizi önlem alınmıştır. ${ }^{12}$ Son olarak, Sanayi ve Teknoloji Bakanlı̆̆ı, Kalkınma Ajansları aracılığıyla 31.03.2020'de üç aşamalı bir eylem planı hazırlamıştır. Planla, virüsün yayılımının önlenmesi ve kontrol altına alınması, halk sağlığı için acil hazırlık ve müdahale çalışmaları, salgının ülke ve bölge ekonomisine negatif etkilerinin azaltılması esas alınmıştır.

\subsubsection{Vergi ve Kredi Erteleme ve Muafiyetleri}

24 Mart tarihinde 1.9 milyon kişi mücbir sebep hali kapsamına alınmış, Nisan, Mayıs ve Haziran'da muhtasar beyanname ve KDV beyannamelerine ilişkin ödemeler 6 ay ertelenmiş, konaklama vergisi kasım ayına kadar ötelenmiş, sokağa çıkma yasağı bulunanların beyanname ve ödemeleri yasak dönemi sonrasına kadar ertelenmiş, Halkbank'ın tüm esnafa 25 bin TL nakit kredi ve 25 bin TL ticari kart vermesi desteği sağlanmıştır. Yine ilk önce 65 yaş ve üzeri ile kronik rahatsızlığı olan vatandaşlar için getirilen araç muayene ertelemesi daha sonra genelleştirilmiştir.

\subsubsection{Sağlık Altyapısının Güçlendirilmesi}

$\mathrm{Bu}$ dönemde kamu görevlilerinin izne bağlı olarak yurtdışına çıkmaları, yurt dışından Türkiye'ye gelen vatandaşların da kendilerini 14 gün tecrit etmeleri kararı alınmıştır. Kamu çalışanlarından kronik hastalığı olanların kolaylıkla izne ayrılabileceği, sağlık personelinin ek ödemelerinin üç ay boyunca iyileştirileceği ve 32 bin yeni personelinin istihdam edilmesi kararları alınmıştır. Öte yandan bu süreçte sağlık altyapısının güçlendirilmesi için, 6 Nisan 2020 tarihinde Cumhurbaşkanı, Atatürk Havalimanı ve Sancaktepe'de 1000'er yataklı hastanenin 45 gün içinde tamamlanacağı bilgisini vermiştir. Ayrıca, İstanbul'da Marmara Üniversitesi Pendik Başıüyük Eğitim ve Araştırma Hastanesi'nin Hizmet Binası açılmış ve KOVID-19 pandemisi kapsamında hasta kabulüne başlamıştır. Başakşehir İkitelli Şehir Hastanesi'nin yollarının 20 Mayıs'a kadar Ulaştırma ve Altyapı Bakanlığı tarafından tamamlanacağı duyurulmuştur.

\subsubsection{Sosyal Yardım ve Toplumsal Dayanışmanın Güçlendirilmesi}

21 Mart 2020'de sosyal yardımlardan yararlanan ailelere 1000 'er lira yardım yapılması kararlaştırılmış olmasına karşın, başlangıçta ailelerin paralarını kendilerinin çekmesi uygulaması varken sosyal mesafenin korunması için bu kez PTT görevlilerince bu ailelere yardım paraları evlerinden ödenmeye başlanmıştır. Yükseköğrenim yurtlarında kalan öğrencilerden, Mart ayında yurtta kalmadıkları günlerin ücretlerinin iade edilmesi Nisan, Mayıs ve Haziran ayları için ücret alınmaması ve burs kredi ödemelerinin devam etmesi kararlaştırılmıştır. Ayrıca vali ve kaymakamların başkanlığında tek başına yaşayan ve ihtiyaçlarını karşılayacak yakını bulunmayan 65 yaş ve üstü ile kronik rahatsızlığı olan vatandaşlar için Vefa Sosyal Destek Grubu oluşturulmuştur. Yeni bir uygulama olarak nitelendirilebilecek ve kamuoyundan olumlu tepkiler alan Vefa Sosyal Destek Grubu'nun il/ilçe emniyet müdürü, il/ilçe jandarma komutanı, vali/kaymakamlar tarafindan belirlenecek kamu kurum ve kuruluşlarının temsilcileri, yerel yönetimler, AFAD, Kızılay ve ihtiyaç duyulacak sivil toplum kuruluşları temsilcilerinden oluşturulmaktadır. Ayrıca bu grubun kararı, görevlendirmesi, koordinasyonu olmadan hiçbir kurum, kuruluş ve STK tarafından yardım faaliyeti gerçekleştirilmeyeceği de belirtilmektedir. Bu kapsamda 4 Mayıs 2020 tarihi itibariyle tutarı 200 milyar TL'yi aşan finansman ve sosyal destek yardımı ve 4 milyon 400 bin vatandaşa biner lira nakdi yardım yapıldığı bildirilmiştir. Ayrıca, 57 farklı ülkeye maske, tulum, tanı kiti, solunum cihazı gibi tıbbi malzeme yardımları yapılarak uluslararası kamuoyunda bir farkl11ık oluşturulmuştur (www.tccb.gov.tr, 2020).

12500 bin liranın altındaki konutlarda kredilendirilebilir miktarın yüzde 80'den yüzde 90'a çıkartılması, asgari peşinatın yüzde 10'a düşürülmesi, otel kiralamalarına ilişkin irtifak hakkı bedelleri ve hasılat payı ödemelerinin nisan, mayıs ve haziran ayları için 6 ay ertelenmesi, nakit akışı bozulan firmaların bankalara olan kredi anapara ve faiz ödemelerinin asgari 3 ay ötelenmesi ve gerektiğinde bunlara ilave finansman desteği sağlanması, ihracatçıya stok finansmanı desteği verilmesi, Kredi Garanti Fonu limitinin 25 milyar liradan 50 milyar liraya çıkarılması, kısa çalışma ödeneğinin getirilmesi, en düşük emekli maaşının 1500 liraya yükseltilmesi, asgari ücret desteğinin devam ettirilmesi ve ihtiyaç sahibi ailelere yapılacak nakdi yardımlar için ilave 2 milyar liralık kaynak ayrılması, mevzuattaki esnek ve uzaktan çalışma modelleri daha etkin hale getirilmesi, emeklilerin bayram ikramiyesinin Nisan ayı başında ödenmesi, istihdamdaki sürekliliği temin etmek amacıyla 2 aylık telafi çalışma süresinin 4 aya çıkarılması, tek başına yaşayan 80 yaş üstü yaşlılar için, sosyal hizmet ve evde sağlık hizmetlerinden oluşan periyodik takip programının uygulanması gibi önlemler alınmıştır. 
13.04.2020 tarihli ve 2399 sayılı Cumhurbaşkanlığı Kararı ile sağlı güvencesi olmayan tüm vatandaşlara Koronavirüs tedavi imkânları sağlanmıştır (Resmi Gazete, 14.04.2020). Diğer yandan, Koronavirüs salgını nedeniyle yiyecek bulmakta zorlanan sokak hayvanları için hayvanların yaşam alanlarına mama, yem ve su bırakılması kararlaştırılmıştır. $\mathrm{Bu}$ süreçte dikkat çeken gelişmelerden biri 30 Mart 2020 tarihinde Cumhurbaşkanı Erdoğan tarafından başlatılan "Biz Bize Yeteriz Türkiyem” yardım kampanyası olmuştur. Bu kapsamda 1 milyar 910 milyon TL bağış toplanmıştır. Ancak, daha önce, Ankara, İstanbul, Konya, Gaziantep büyükşehir ve bazı ilçe belediyeleri yardım kampanyaları başlatmıştır. Bu kampanyaların durdurulması ve tek merkezden yürütüleceğinin açıklanması ise bir başka tartışmaya konu olmuştur ${ }^{13}$.

\section{AŞAMALI NORMALLEŞME İÇİN “KONTROLLÜ SOSYAL HAYAT"}

Çin, ilk KOVID-19 vakasını 1 Aralık 2019 tarihinde açıklamıştır. Bu tarihten itibaren önce Çin'e komşu ülkelerde sonrasında dünya genelinde özellikle Avrupa ülkelerinde ilk vakalar açıklanmaya başlanmıştır. İlk vakanın Türkiye'de görüldüğü 11 Mart 2020 tarihine kadar dünya genelinde tanı konulan vaka sayısı 119 bin 132, vefat sayıs1 4 bin 284 olarak belirtilmektedir (www.cnnturk, 09.03.2020). Türkiye, ilk vakanın ortaya çıkmasından çok önce bu çalışmanın da kapsamını oluşturan risk yönetimi perspektifinde önleyici tedbirler ve çalışmalar gerçekleştirmiş̧ir. 11 Mart 2020 tarihine kadar virüsü Türkiye sınırlarının dışında tutabilmenin de başarılı bir risk yönetiminin sonucu olduğu söylenebilir. Şekil 7'de 11 Mart 2020 öncesi dünya genelinde Koronavirüs yayılımı görülmektedir.

Şekil 7. Dünya Geneli Koronavirüs Yayılım Haritası

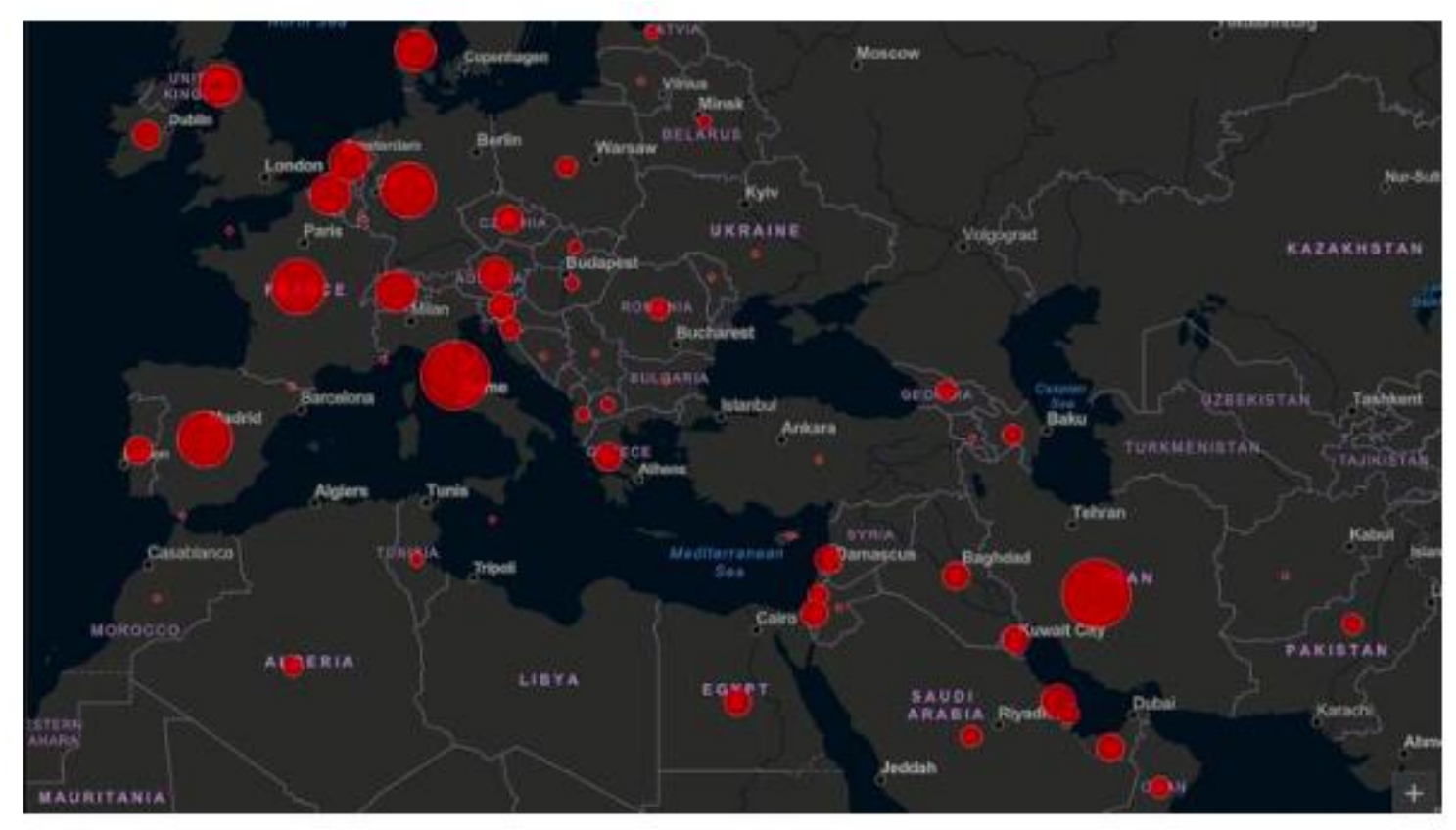

Kaynak: CNN Türk (2020a), Koronavirüs Son Durum

İlk vakanın görülmesi sonrası ise kriz yönetimine geçilmiş ve böylelikle mücadele süreci başlamıştır. Vakanın açıklanması ile ilk günden itibaren son derece şeffaf bir süreç yürütüldügü görülmektedir. Sağlık Bakanı tarafından her gün ilgili veriler çoğunlukla tüm TV kanallarından, bazı günler de sosyal medya hesaplarından paylaşılmıştır. $\mathrm{Bu}$ süreçte bakanın canlı olarak bilgi verdiği toplantılar, tüm basın mensuplarının katılımı gözetilerek ve verilerin açıklanması sonrası basın mensuplarının soru yöneltmeleri ile gerçekleşmiştir. Her akşam aynı saatlerde aksatılmadan yapılan bu toplantılar, halkta güveni arttırmış ve izlenen politikalara katılımını kolaylaştırmıştır. Şekil 8'de 4 Mayıs 2020 tarihine ait verilerin açıklandığı örnek bir vaka tablosu gösterilmektedir.

13 Merkez-yerel ilişkileri bağlamında yaşanan gelişmeler çok yönlü olarak incelenebilir ancak çalışmanın kısıtları ve kapsamı nedeniyle burada yer verilememiştir. 


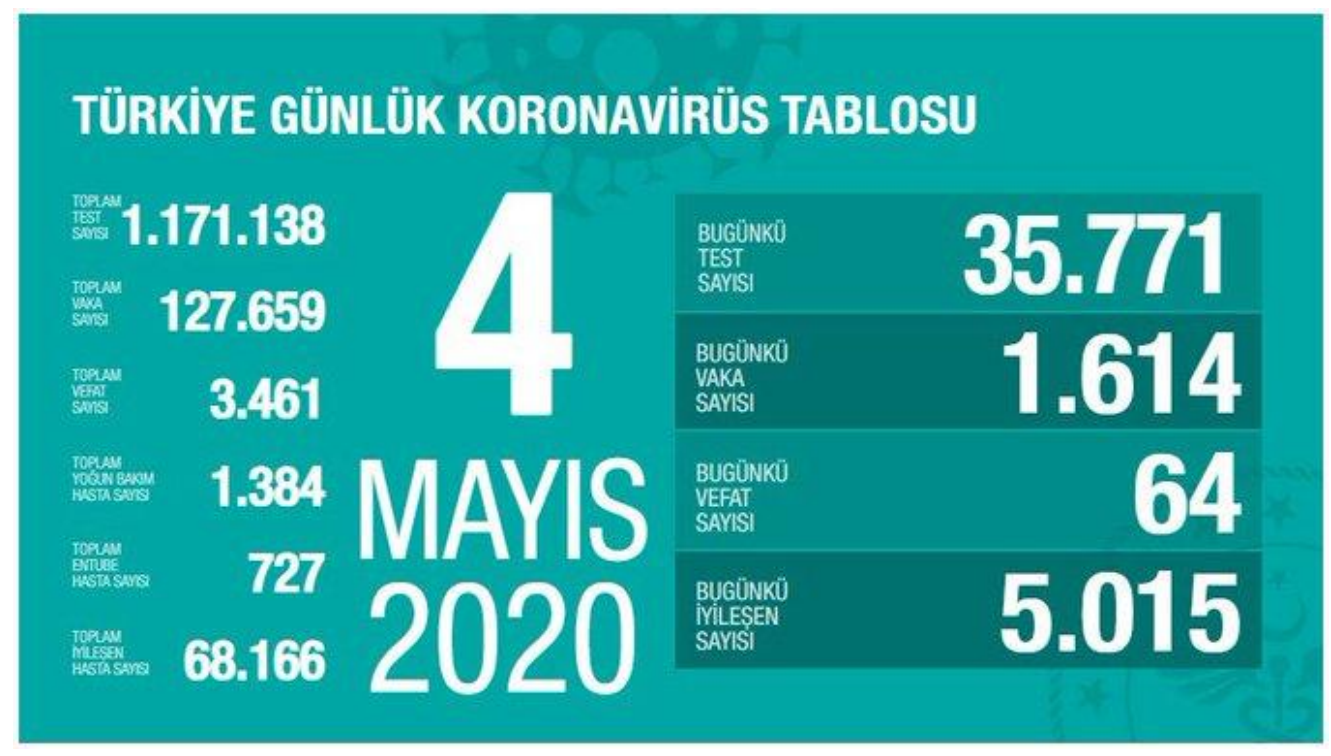

Kaynak: Koca, 2020.

Şekil 8'de görüldügü gibi günün tarihi büyük puntolar ile ortada yer almakta, sağ sütunda günlük test sayıs1, vaka sayısı, vefat sayısı ve iyileşen hasta sayıları bulunmaktadır. Sol sütunda ise ilgili tarihe kadar yapılan toplam test sayısı, vaka ve vefat sayıları ile yoğun bakımda yatan hasta sayısı ile entübe edilen (solunum cihazına bağlanan) hasta sayıları ve iyileşen hasta sayısı verilmektedir. Tabloda görüldüğü üzere günlük vaka sayısı 1614 kişi, iyileşen vaka sayısı ise 5015 kişidir. İyileşen hasta sayısının, vaka sayısını geçmesi durumu birçok uzman tarafından önemli bir eşik olarak kabul edilmektedir. 4 Mayıs itibariyle, iki rakam arası oldukça açılmıştır.

65 yaş ve üstü ile 20 yaş ve altı vatandaşların sokağa çıkma kısıtlaması ile vefat vakalarında ciddi oranda azalma olmuştur. Yoğun bakım süreçleri de azalmıştır. Türkiye'deki yoğun bakım doluluk oranı yüzde 60 olarak açıklanmıştır. Tüm hastanelerde KOVID-19 nedenli servis yatakları doluluk oranı sadece 1/3 olarak ifade edilmiştir. Entübe edilenler yüzde 58'den yüzde 10'a kadar düşmüş, Türkiye yüzde 2,3 ile en düşük ölüm oranına sahip ülkelerden biri olmuştur (www.saglik.gov.tr, 2020b). Bu durum, Sağlık Bakanlığı Bilim Kurulu tarafından yürütülen Türkiye'ye özgü geliştirilen tedavi algoritmasına dayandırılmaktadır. Türkiye, vakaların ilk kez görüldüğü Çin ve sonrasında yüksek ivmeyle devam ettiği İtalya'da uygulanan tedavi süreçlerini değerlendirip kendi algoritmasını oluşturmuştur. Sonrasında ise diğer ülkelere bu tecrübesini aktarmaya devam etmektedir. Sağlık Bakanı, 23 Nisan'da yaptığı konuşmada İngiliz mevkidaşı ile telefon görüşmesi yaptıklarını ve Türkiye'nin tecrübelerini aktardığını ifade etmiştir (www.saglik.gov.tr, 2020a).

Ölüm ve vaka sayılarındaki azalış ile birlikte Türkiye'de kriz yönetiminin bir başka aşaması olan yeniden inşa aşaması olarak da nitelendirilebilecek aşamalı bir normalleşme sürecine geçilmiş̧ir. Sağlık Bakanlı̆̆ tarafından "kontrollü sosyal hayat" kavramıyla ifade edilen bu aşamada yine tedbir politikasının izlendiği gözlemlenmektedir. $\mathrm{Bu}$ sürece geçmek üzere bazı alanlardaki kısıtlamalar tedbirleri içerecek şekilde kaldırılmıştır. Bu kapsamda gerçekleştirilen düzenlemeler şunlardır (www.tccb.gov.tr, 2020);

- 65 yaş üstü gruba, sokağa çıkma sınırlandırması günlerinin birinde ve dört saat süreyle, yürüme mesafesiyle tahditli olarak dışarı çıkabilme ve 20 yaş altı için bu esnemenin iki grup hâlinde uygulanması.

- 31 ilde uygulanan şehirlerarası giriş-çıkış sınırlandırmasının, 4 Mayıs 2020'den itibaren Antalya, Aydın, Erzurum, Hatay, Malatya, Mersin ve Muğla illeri için kaldırılması ve diğer 24 ildeki giriş-çıkış sınırlamasının 15 gün süreyle uzatılması.

- İstanbul, Ankara ve İzmir'deki ticari taksiler için tek-çift plaka uygulamasının 5 Mayıs 2020 itibariyle sona erdirilmesi.

- Belirlenen şartlara uymak kaydıyla berber, kuaför, güzellik salonu gibi işletmeler, alışveriş merkezleri, giyim eşyası, ayakkabı, çanta, zücaciye gibi ürünlerin satıldığ işletmelerin 11 Mayıs 2020'de hizmete açılması. 
- Askerlik terhis işlemlerinin 31 Mayıs'ta, Millî Savunma Bakanlığının atama, görevlendirme ve personel temin faaliyetlerinin 1 Haziran'da, celp işlemlerinin 5 Haziran'da, bedelli askerlik işlemlerinin ise 20 Haziran'da yeniden başlaması.

- Belediyelerin kredi işlemleri ile İller Bankası ihalelerinin 27 Mayıs'ta yeniden açılması.

- Yükseköğretim Kurumları Sınavının 27-28 Haziran'da, Liselere Geçiş Sınavının 20 Haziran'da, Askerî Öğrenci Sınavının 14 Haziran'da yapılması ve üniversitelerin 15 Haziran'da akademik takvime dönmesi.

\section{SONUÇ}

Salgınlar insanlık tarihi boyunca mücadele edilmesi gereken bir tür biyolojik afet olarak nitelendirilmektedir. Salgınlar kimi zaman kendileri bir afet, kimi zaman da başka afetler sırasında ve sonrasında ortaya çıkan bir afet türüdür. Her iki durumda da salgınlar afet yönetimi sürecinin iki önemli unsuru olan risk yönetimi ve kriz yönetimi süreçleri gözetilerek ele alınmalıdır. Ancak her afetin etkisi, boyutları, afete müdahale etme biçimi farklılık arz etmekte olduğu için kendine özgü aşamaları bulunmaktadır. Salgınlarda, salgının ortaya çıkmasını önleme, salgına hazırlıklı olma ve salgın riskini azaltma sürecini içeren risk yönetimi aşaması bulunmaktadır. Ancak Beck ve Giddens gibi düşünürler tarafindan geliştirilen risk toplumu kavramı ve belirsizlik olgusu, risk yönetimi sürecinin özellikle salgınlar sözkonusu olduğunda belirli zorluklar içerdiğini göstermektedir. Üstelik bu süreçte alınan her karar ve gerçekleştirilen her müdahalenin başka riskler ve belirsizliklere yol açtığını belirtmek gerekir. Risk toplumunun doğasında var olan belirsizliklere karşı önceden alınan önlemlerin başarısı toplumun dirençlilik potansiyelidir. Dirençli toplum olarak kavramsallaştırılan bu yeni yaklaşım, afetlere karşı bütün yönleriyle hazırlıklı olabilen bir toplumsal yapının inşa edilmesi anlamına gelmektedir.

Gelinen süreçte bir anda ortaya çıkan, ölümcül ve yayılma hızı son derece yüksek olan ve bu yönüyle küreselleşen KOVID-19 salgını insan toplumlarını ve devletleri önce çaresizliğe sonra da belirsizliğe sürüklemiş, sınırlar kapanmış, ulaşım ve dolaşım yasaklanmış, önce devletler sonra da şehirler adeta karantinaya alınmış, bütün dünyada neredeyse olağanüstü hal ilan edilmiştir. Aslında risk toplumu kavramı anlatılırken değinildiği üzere olağanüstü halin olağanlaştığı bir sürece geçilmiş̧tir. Risk yönetimi faktörlerinin bu yoğunluğu ve karmaşıklığı toplumların ve devletlerin hazırlıksız yakalanmasına yol açmış olduğu için kriz yönetimi süreci devreye sokulmuş ve başlangıçta olmasa da kısa süre içinde bütün devletler toplumsal bilinçlendirme, acil müdahale, salgının yayılmasını engelleme stratejisini uygulamaya başlamış eş zamanlı olarak da ekonomik önlemlerin alınması, toplumsal düzenin sağlanması ve dayanışmanın güçlendirilmesi gibi iyileştirme çalışmalarını başlatmışlardır. Bu süreçlerin bir döngü halinde kimi zamanda eş anlı olarak uygulandığı izlenmektedir. Bundan sonraki süreçte de aşamalı olarak alınan tedbirlerin yumuşatılarak olağan bir sürece geçişin adımlarının atılacağını belirtmek gerekir. Ancak afet yönetimi açısından değerlendirilen risk yönetimi ve kriz yönetimi süreçlerinin kamu politikası analizlerinde ve yaklaşımlarında yeterince ele alınmamasından yola çıkılarak bu iki sürecin kamu politikası açısından da değerlendirilmesi gerekmektedir. Çalışmada kamu politikası analizi ve yaklaşımlarında risk yönetimi ve kriz yönetimi süreçleri aktörler ve politikalar ilişkisi bakımından süreç yaklaşımı kullanılarak ele alındığında, salgın probleminin tanımlanıp gündeme alınması, çözüm stratejileri için öneriler geliştirilmesi, katılım mekanizmalarının çalıştırılması, kararların Bilim Kurulu tavsiyeleri doğrultusunda kanıta dayalı olarak alınması ve bu aşamada tedbir stratejisinin belirlenerek ona uygun hukuki altyapının oluşturulması ve yasal düzenlemeler ile desteklenmesi, benimsenen stratejinin uygulamaya konması ve gelişmelerin anlık olarak değerlendirilip izlenmesi süreçlerinin Türkiye'nin uyguladığı mücadele politikasının analizini kolaylaştırmaktadır.

Türkiye'de ilk vakanın açıklandığı 11 Mart 2020 tarihinden 4 Mayıs $2020^{14}$ tarihine kadar olan mücadele sürecini kamu politikası perspektifinden ele alan bu çalışma, sürece genel hatlarıyla ayna tutmaktadır. Gelinen aşamada Türkiye'de vaka ve ölüm oranlarının azalmasıyla birlikte "Kontrollü Sosyal Hayat" adı verilen aşamalı normalleşme çalışmalarına başlanmıştır. $\mathrm{Bu}$ anlamda salgın sonrası nasıl bir dünya ve nasıl bir Türkiye olacağına dair çeşitli tartışmalar yürütülerek geleceğe dair senaryolar üzerinde çalışılmaktadır. Kimi senaryolara göre dünyanın ve doğal olarak devletlerin daha kapalı ve otoriter bir yapıya doğru evrileceği ve devlet müdahalelerinin artacağı, kimi senaryolara göre de daha demokratik bir küresel sistem kurulacağı öngörülmektedir.

14 Çalışmanın sonlandırılması için seçilen 4 Mayıs 2020 tarihi, aşamalı normalleşme için "Kontrollü Sosyal Hayat" sürecine geçildiğinin ilan edildiği tarihtir. 


\section{KAYNAKÇA}

AFAD (2020), Doğal Afetler, Afet ve Acil Durum Yönetimi Başkanlığı Yayını, Ankara, https://www.afad.gov.tr/afadem/dogal-afetler (Erişim Tarihi: 30.04.2020).

AVEN, Terje ve RENN, Ortwin (2018), "Improving Government Policy on Risk: Eight Key Principles", Reliability Engineering And System Safety, S.176, ss.230-241.

BABAOĞLU, Cenay (2017), “Kamu Politikası Analizine Yönelik Kavramsal ve Kuramsal Bir Çerçeve”, Yönetim Bilimleri Dergisi, S.30(15), ss.511-532.

BABAOĞLU, Cenay ve AKMAN, Elvettin (2018), Kamu Politikası Analizi Türkiye Uygulamaları, Seçkin Yayınc1lık, Ankara.

BAŞAĞAOĞLU, İbrahim, UÇAR, Doğan ve AHMET, Osman (2015), Osmanlı'da Salgın Hastalıklarla Mücadele, Çamlıca Kitabevi, İstanbul.

BECK, Ulrich (1986), Risk Toplumu (Çev. Kazım Özdoğan, Bülent Doğan), İthaki Yayınları, İstanbul, 2.Bask1.

CHAN, Emily Ying Yang ve SHAW, Raymond (2020), Public Health and Disasters: Health Emergency and Disaster Risk Management in Asia, Springer, Singapore.

CNN TÜRK (2020a), "Koronavirüs Son Durum 11 Mart”, E-Haber, https://www.cnnturk.com/turkiye/coronavirus-son-durum-9-mart-iste-corona-virusu-haritasi (Erişim Tarihi: 09.04.2020).

CNN TÜRK (2020b), "Sinırdan dönen göçmenlere sağlık kontrolü yapıldı", E-Haber, https://www.cnnturk.com/turkiye/sinirdan-donen-gocmenlere-saglik-kontrolu-yapildi, (Erişim Tarihi: 09.04.2020).

ÇAĞATAY, Güler ve ÇOBANOĞLU, Zakir (1994), Afetler, Sağlık Bakanlığı Yayınları, Ankara.

DIYANET İŞLERİ BAŞKANLIĞI (2020), Diyanet İşleri Başkanlığı'ndan Koronavirüse Karşı Alınan Tedbirlerle Ilgili Açılama, 15 Mart 2020, https://www.diyanet.gov.tr/trTR/Kurumsal/Detay/29397/diyanet-isleri-baskanligindan-koronaviruse-karsi-alinan-tedbirlerle-ilgiliaciklama (Erişim Tarihi: 25.04.2020).

DJALANTE, Riyanti, SHAW, Rajib ve DEWIT, Andrew (2020), "Building Resilience Against Biological Hazards And Pandemics: COVID-19 And its Implications For The Sendai Framework", Progress in Disaster Science, S.6(100080) , www.elsevier.com/locate/pdisas (Erişim Tarihi: 25.04.2020).

DUFFIN, Erin (2020), Impact of The Coronavirus Pandemic on The Global Economy - Statistics \& Facts, https://www.statista.com/topics/6139/covid-19-impact-on-the-globaleconomy/\#dossierSummary_chapter1 (Erişim Tarihi: 25.04.2020).

DURAN, Hazal (2020), Devletlerin Koronavirüsle Karşılaştırmalı Mücadele Stratejileri, SETA Yayınları, Ankara.

DÜNYA SAĞLIK ÖRGÜTÜ - DSÖ (2019), Sağlık Acil Afet Risk Yönetimi -Health Emergency and Disaster Risk Management Framework (Health -EDRM), World Health Organization, Switzerland, https://www.who.int/hac/techguidance/preparedness/health-emergency-and-disaster-risk-managementframework-eng.pdf?ua=1 (Erişim Tarihi: 03.05.2020).

DÜNYA SAĞLIK ÖRGÜTÜ - DSÖ (2020), Coronavirus (COVID-19) Dashboard, https://covid19.who.int/ (Erişim Tarihi: 03.05.2020).

EYİDOĞAN, Haluk (2020), “COVID-19 Salgını ve Afet Yönetimi”, Bilim ve Gelecek Dergisi, S.192.

GIDDENS, Antony (1999), "Risk", The British Broadcasting Corporation (BBC), http://news.bbc.co.uk/hi/english/static/events/reith_99/week2/week2.htm (Erişim Tarihi: 03.05.2020).

GÖKÇEKUŞ, Hüseyin, BARLAS, Ceren, ALMUHISEN, Maram ve EYNİ, Nima (2018), Doğal ve İnsan Kaynaklı Afetler, Sonuçları ve Afet Yönetimi, Yakın Doğu Üniversitesi Yayınları, Lefkoşa, http://www.iusarc.org/wp-content/uploads/2018/06/Do\%C4\%9Fal-ve-\%C4\%B0nsan-Kaynak1\%C4\%B1Felaketler-Sonu\%C3\%A7lar\%C4\%B1-ve-Afet-Y\%C3\%B6netimi.pdf (Erişim Tarihi: 30.04.2020). 
TURAN, Abdulmenaf ve ÇELIKKYAY, Hicran HAMZA - Türkiye'de KOVID-19 ile Mücadele: Politikalar ve Aktörler

GÜNGÖR, Yıldırım (t.y.), “Dünyayı Etkileyen Önemli Afetler ve Alınan Dersler”, Ders Notları, İstanbul Üniversitesi Yayını, İstanbul, https://auzefalmsstorage.blob.core.windows.net/auzefcontent/ders/dunyayi_etkileyen_onemli_afetler_ve_ alinan_dersler/index.html (Erişim Tarihi: 30.04.2020).

İÇIŞLERİ BAKANLIĞI (2020), "Koronavirüs Salgını ile Mücadele Kapsamında Marketlerle İlgili Ek Genelge”, 24.03.2020, Genelge, https://www.icisleri.gov.tr/koronavirus-salgini-ile-mucadelekapsaminda-marketlerle-ilgili-ek-genelge (Erişim Tarihi: 02.05.2020).

İÇIŞLERİ BAKANLIĞI (2020), "Koronavirüs Salgını ile Mücadele Kapsamında Toplantılarla Ilgili Ek Genelge”, 26.03.2020, Genelge, https://www.icisleri.gov.tr/koronavirus-salgini-ile-mucadelekapsaminda-toplantilarla-ilgili-ek-genelge (Erişim Tarihi: 03.05.2020).

İÇIŞLERI BAKANLIĞI (2020), 03.04.2020, “Şehir Giriş/Çıkış Tedbirleri ve Yaş Sinırlaması", Genelge, https://www.icisleri.gov.tr/sehir-giriscikis-tebirleri-ve-yas-sinirlamasi (Erişim Tarihi: 03.05.2020).

İÇiŞLERİ BAKANLIĞI (2020), “2 Gün Sokağa Çıkma Yasağı”, 10.04.2020, Genelge, https://www.icisleri.gov.tr/2-gun-sokaga-cikma-yasagi (Erişim Tarihi: 03.05.2020).

KNIGHT, Frank H. (1921), Risk, Uncertanity and Profit, Houhgton Mifflin Company, Boston and Newyork.

KOCA, Fahrettin (2020), Twitter (Sosyal Medya) Paylaşımı, @drfahrettinkoca, 04.05.2020, https://twitter.com/drfahrettinkoca/status/1257359346310266880

KUPFERSCHMIDT, Kai ve COHEN, Jon (2020), “Can China's COVID-19 Strategy Work Elsewhere?", Science, S.367(6482), ss.1061-1062, https://science.sciencemag.org/content/367/6482/1061/tab-pdf (Erişim Tarihi: 03.05.2020).

LACAMBRA, Sergio, SUAREZ, Gines, HORİ, Tsuneki, ROGERS, Cassandra, SALAZAR, Lina, ESQUIVEL, Maricarmen, NARVAEZ, Lizardo, CARDONA, Omar Dario, DURAN, Rolando, TORRES Ana Maria, SANAHUJA, Haris, OSORIO, Claudio, CALVO, Jorge, GILBERTO Romero ve VISSCONTİ, Ernesto (2015), "Index of Governance and Public Policy in Disaster Risk Management (iGOPP) Environment, Rural Development and Disaster Risk Management Division", Inter-American Development Bank, https://publications.iadb.org/publications/english/document/iGOPP-Index-of-Governance-and-PublicPolicy-in-Disaster-Risk-Management.pdf (Erişim Tarihi: 03.05.2020).

LePAN, Nicholas (2020), "Visualizing the History of Pandemics", VisulaCapitalist, 14 Mart 2020, https://www.visualcapitalist.com/history-of-pandemics-deadliest/ (Erişim Tarihi: 03.05.2020).

MAHAR, Irfan (2020), Impact of Covid-19 on Global Economy Structure, 22 Nisan 2020, https://moderndiplomacy.eu/2020/04/22/impact-of-covid-19-on-global-economy-structure/ (Erişim Tarihi: 03.05.2020).

O'GRADY, Cathleen (2020), “The U.K. Backed Off on Herd Immunity. To Beat COVID-19, We'll Ultimately Need it", National Geography, 20 Mart 2020, https://www.nationalgeographic.com/science/2020/03/ukbacked-off-on-herd-immunity-to-beat-coronavirus-we-need-it/ (Erişim Tarihi: 03.05.2020).

PAMUK, Şevket (2020), "Tarihte Küresel Salginlar ve Iktisadi Sonuçları", Sarkaç Bülten, 9 Nisan 2020, https://sarkac.org/2020/04/tarihte-kuresel-salginlar-ve-iktisadi-sonuclari/ (Erişim Tarihi: 03.05.2020).

PEKCAN, Ruhsar (2020), Twitter (Sosyal Medya) Paylaşımı, @pekcan, (03.04.2020), Periscope Yayını, https://www.pscp.tv/w/1YqKDEwzVoOGV (Erişim Tarihi: 03.05.2020).

RESMI GAZETE (2020), 13.04.2020 tarihli ve 2399 Sayılı Cumhurbaşkanı Kararı (14.04.2020 tarih ve 31099 say1l1 Resmi Gazete), https://www.resmigazete.gov.tr/eskiler/2020/04/20200414.pdf (Erişim Tarihi: 03.05.2020).

ROBINSON, Scott Everett ve WEHDE, Wesley (2020), "Public Administration in The Time of COVID-19", Journal of Public Administration Research and Theory, S.(Virtual Issue), https://static.primary.prod.gcms.the-infra.com/static/site/jpart/document/jpart\%20covid19\%20introduction.pdf?node=b473da46247cea9e3eb1 (Erişim Tarihi: 03.05.2020).

SABAH GAZETESİ, (2020), “Gö̧̧menlerin Umutlarını Corona Vurdu! Şimdi De Karantina...”, E-Haber, https://www.sabah.com.tr/galeri/turkiye/gocmenlerin-umutlarini-corona-vurdu-simdi-de-karantina/3 (Erişim Tarihi: 15.04.2020). 
SAĞLIK BAKANLIĞI (2020a), “Sağlık Bakanı Fahrettin Koca, İngiliz ve Rus Mevkidaşlartyla Görüştü”, EHaber, https://www.saglik.gov.tr/TR,65235/saglik-bakani-fahrettin-koca-ingiliz-ve-rus-mevkidaslariylagorustu.html (Erişim Tarihi: 30.04.2020).

SAĞLIK BAKANLIĞI (2020b), “Yoğun Bakım Yatak Doluluk Oranımızı Yüzde 60’lara İndirdik”, E-Haber, https://www.saglik.gov.tr/TR,65192/yogun-bakim-yatak-doluluk-oranimizi-yuzde-60lara-indirdik.html (Erişim Tarihi: 30.04 .2020 ).

TCCB - CUMHURBAŞKANLIĞI (2020), “Normal Hayata Dönüşü Kademe Kademe Başlatacağız”, E-Haber, https://www.tccb.gov.tr/haberler/410/119206/-normal-hayata-donusu-kademe-kademe-baslatacagiz(Erişim Tarihi: 04.05.2020).

TÜRK DİL KURUMU (2020), Sözlük, TDK Yayını, Ankara, www.tdk.gov.tr (Erişim Tarihi: 02.05.2020).

UNDRR - BİRLEŞMISS MILLETLER AFET RISSK AZALTMA OFİSİ (2015), Sendai Afet Riskini Azaltma Çerçevesi, https://www.undrr.org/implementing-sendai-framework/what-sf (Erişim Tarihi: 30.04.2020).

USTA, Aydın (2013), “Kamu Politikaları Analizine Kuramsal Bir Bakış”, Yasama Dergisi, S.24(Parlamento Hukuku Özel Sayıs1 I), ss.78-102, http:// www.yasader.org/wp/?page_id=110 (Erişim Tarihi: 28.04.2020).

WWW WORLD WILD LIFE (2020), E-Article, https://www.worldwildlife.org/stories/what-is-a-pangolin (Erişim Tarihi: 02.05.2020).

YALÇINKAYA, Hikmet (2020), “Uzmanları Bir Araya Getiren 'Bilim Kurulu' Nasıl Kuruldu?”, E-Haber, https://www.gzt.com/jurnalist/uzmanlari-bir-araya-getiren-bilim-kurulu-nasil-kuruldu-3531656 (Erişim Tarihi: 25.03.2020).

YENER, Duygu (2020), “Türkiye'nin Koronavirüsle Mücadele Politikasına 'Bilim Kurulu' Yön Veriyor”, Anadolu Ajansi, $24 \quad$ Mart https://web.archive.org/web/20200328180255/https://www.aa.com.tr/tr/koronavirus/turkiyeninkoronavirusle-mucadele-politikasina-bilim-kurulu-yon-veriyor/1777215 (Erişim Tarihi: 25.04.2020).

YILDIZ, Mete ve SOBACI, Mehmet Zahid (2013), Kamu Politikası: Kuram ve Uygulama, Adres Yayınları, Ankara. 